\title{
The role of bacterial and algal exopolymeric substances in iron chemistry.
}

Louiza Norman $^{1 *}+$, Isabelle A. M. Worms ${ }^{2}$, Emilie Angles ${ }^{1,3+\dagger}$, Andrew R. Bowie ${ }^{4,5}$, Carol Mancuso Nichols ${ }^{6}$, A. Ninh Pham ${ }^{7}$, Vera I. Slaveykova², Ashley T. Townsend ${ }^{8}$, T. David Waite $^{7}$, and Christel S. Hassler ${ }^{1,9}$

\section{Affiliations}

${ }^{1}$ University of Technology Sydney, Plant Functional Biology and Climate Change Cluster, PO Box 123, Broadway 2007, NSW, Australia.

${ }^{2}$ University of Geneva, Faculty of Science, Earth and Environmental Sciences, Institute F.-A. Forel, Environmental Biogeochemistry and Ecotoxicology, 10 rte de Suisse, 1290 Versoix, Switzerland.

${ }^{3}$ CSIRO Marine and Atmospheric Research, PO Box 1538, Hobart 7001, TAS, Australia.

${ }^{4}$ Antarctic Climate and Ecosystems CRC, Private Bag 80, Hobart, TAS 7001, Australia ${ }^{5}$ Institute for Marine and Antarctic Studies, University of Tasmania, Private Bag 129, Hobart, TAS 7001, Australia

${ }^{6}$ CSIRO Materials Science \& Engineering, c/o CSIRO Marine and Atmospheric Research, PO Box 1538, Hobart 7001, TAS, Australia.

${ }^{7}$ UNSW Water Research Centre, School of Civil and Environmental Engineering, The University of New South Wales, Sydney, NSW 2052, Australia

${ }^{8}$ Central Science Laboratory, University of Tasmania, Private Bag 74, Tasmania, 7001, Australia

${ }^{9}$ University of Geneva, Faculty of Science, Earth and Environmental Sciences, Institute F.-A. Forel, Marine and Lake Biogeochemistry, 10 rte de Suisse, 1290 Versoix, Switzerland.

*Correspondence to: ln293@cam.ac.uk

† Current address: Department of Plant Sciences, University of Cambridge, Downing Street, Cambridge, CB2 3EA, UK.

††Current address: Université de Nantes, GEPEA, UMR-CNRS 6144, Bd de l'Université, CRTT-BP406, 44602 Saint Nazaire Cedex, France. 


\begin{abstract}
It is widely accepted that the complexation of iron $(\mathrm{Fe})$ with organic compounds is the primary factor that regulates Fe reactivity and its bioavailability to phytoplankton in the open ocean. Despite considerable efforts to unravel the provenance of the many organic ligands present in the 'ligand soup' and their contribution to Fe chemistry, much of this pool remains largely unresolved. Bacteria and phytoplankton are known to release exopolymeric substances (EPS) for a variety of functions and it is known that this material has metal binding properties. However, the contribution that bacterial and algal EPS makes to Fe biogeochemistry is not well documented. This study revealed that both bacterial and algal EPS contain functional components known to bind Fe (uronic acid, saccharides) and details the molecular weight distribution of the EPS. It is also demonstrated that components of the EPS have a high affinity for Fe-binding, in some cases similar to that of bacterial siderophores ( $\left.\sim \mathrm{K}_{\mathrm{Fe}} \mathrm{L} 10^{12}\right)$ and that this material greatly enhances Fe solubility (and, possibly, Fe oxyhydroxide reactivity via prevention of aggregation) in seawater. However, EPS may also accelerate Fe(II) oxidation and thus Fe(II) removal from the system. Our findings indicate that, in remote ocean regions, bacterial and algal EPS could play a significant role in the biogeochemical cycling of Fe and their contribution should be considered to further our understanding of the dynamics of Fe-limited oceans.
\end{abstract}

Keywords: iron, organic ligand, biogeochemistry, exopolymeric substances 


\section{Introduction}

In large areas of the oceans dissolved Fe concentrations in surface waters can be extremely low, often less than $1 \mathrm{nM}$ (de Baar \& de Jong, 2001). However, the reported concentrations are often higher than the solubility of Fe in surface waters which can be as low as $0.01 \mathrm{nM}$ (pH 8.1, 25 ${ }^{\circ} \mathrm{C}$; Liu and Millero, 2002). It is now well accepted that the reason for this disparity is that almost all of the $\mathrm{dFe}(>99 \%)$ present in the oceans is bound to organic ligands (Gledhill and van den Berg, 1994; Hunter and Boyd, 2007; Rue and Bruland, 1995) and that this complexation is the main factor regulating oceanic Fe reactivity and bioavailability (Hassler et al., 2011a).

Organic complexation can increase Fe solubility and retard hydrolysis and precipitation (Boyd and Ellwood, 2010; Chen et al., 2004; Kuma et al., 1996, 1998; Liu and Millero, 2002), potentially enhancing retention time in surface waters (Tagliabue et al., 2009). Organic complexation also influences Fe redox speciation in seawater (Rijkenberg et al., 2006) as it can slow oxidation kinetics (Croot et al., 2001; Millero et al., 1987; Roy et al., 2008; Santana-Casiano et al., 2000) and mediate direct photo-reduction of Fe(III)-organic ligand complexes (Barbeau et al., 2001, 2003) or the photo-reductive dissolution of colloidal Fe (Waite and Morel, 1984; Waite et al., 1986). However, there are a great variety of Febinding organic ligands (Hunter and Boyd, 2007), many of which remain largely unresolved as to their nature and origin, each potentially having varying affinities for Fe, chemical labilities, and susceptibility to photo-chemical or biological transformation (Amin et al., 2009; Gledhill and Buck, 2012 and refs therein).

Currently the organic ligand pool is poorly characterised. Detection using electrochemical methods (competitive ligand exchange-adsorptive cathodic stripping voltammetry, CLEAdCSV) allows us only to distinguish two discrete organic ligand classes, operationally defined as $L_{1}$ and $L_{2}$, based on their relative binding affinities with Fe (Hunter and Boyd, 2007). $\mathrm{L}_{1}$ class ligands characteristically have a high affinity (strong binding capacity, $\mathrm{K}_{\mathrm{Fe}} \mathrm{L}$ $\geq 10^{12}$ ) for $\mathrm{Fe}$, whereas $\mathrm{L}_{2}$ class ligands have a weaker binding capacity (i.e. $<10^{12}$; Rue \& Bruland, 1995 \&1997). In open ocean systems the concentration of organic ligands are generally in excess of dFe in the water column (Gledhill and Buck, 2012), both as soluble and colloidal forms (Boye et al., 2010). Most are biologically produced in situ by bacterio- and phytoplankton, (Hassler and Schoemann, 2009). Bacterially produced siderophores have been widely studied for Fe-binding and are in the $\mathrm{L}_{1}$ class of ligands (Amin et al., 2009; Barbeau et 
al., 2001, 2003; Gledhill et al., 2004; Hutchins et al., 1999; Maldonado and Price, 1999; Maldonado et al., 2005; Mawji et al., 2008, 2011). Whereas saccharides (Hassler et al., 2011a, b; Steigenberger et al., 2010) and intracellular compounds such as heme (Gledhill and Buck, 2012) are considered to be part of the L2 class of ligands.

Exopolymeric substances (EPS) are a group of, as yet, poorly studied organic ligands that are heterogeneous, polyfunctional macromolecules containing functional groups such as uronic acids, neutral sugars, mono- and polysaccharides, amino acids, and proteins (Hassler et al., 2011a, b; Mancuso Nichols et al., 2005; Verdugo et al., 2004). EPS are produced by both bacteria and algae and fulfil a wide variety of ecological functions such as cryoprotection, halotolerance, chain or colony formation, and substrate attachment (Aluwihare and Repeta, 1999; Decho, 1990; Hoagland et al., 1993). It is likely, therefore, that EPS is present in high concentrations in surface waters (Hassler et al., 2011a). Aggregated EPS also forms a substantial part of both marine transparent exopolymeric substances and marine snow and occurs mainly as colloidal organic matter (Hassler et al., 2011a; Verdugo et al., 2004). Laboratory experiments have shown that Fe bound to bacterial EPS, uronic acids and other polysaccharides (e.g. dextran) can be highly bioavailable to eukaryotic phytoplankton from the Southern Ocean (Hassler and Schoemann, 2009; Hassler et al., 2011a, b, 2014, and this issue). More recently a companion study to this paper (Hassler et al., this issue) demonstrated that Fe bound to algal EPS was not only highly bioavailable, but was also extremely efficient at sustaining the growth and photosynthetic efficiency in the diatom Chaetoceros simplex under laboratory conditions. Whilst several studies have gone some way to chemically characterize bacterial and algal exudates (Aluwihare and Repeta, 1999; Mancuso Nichols et al., 2004, 2005; Nanninga et al., 1996) and investigate their role in Fe bioavailability (Hassler et al., 2011b, and this issue; Steigenberger et al., 2010), marine bacterial and microalgal EPS remain poorly characterized in terms of their effect on Fe chemistry.

The aim of this study was to investigate how bacterial and algal EPS affect Fe chemistry in terms of Fe solubility, the nature of their Fe-binding properties, and redox chemistry. The isolated EPS were also characterized in terms of functional composition, molecular weight distribution, trace element and macronutrient composition, and the contribution of electrochemically detected humic substance-like (HS-like) material. Here we investigated 4 EPS isolates purified from; 1) sea ice bacteria of the genus Pseudoalteromonas (Mancuso Nichols et al., 2004); 2) a natural community (SAZ bloom) obtained from a coccolithophorid 
dominated phytoplankton bloom collected from surface waters of the Sub-Antarctic zone during the austral summer of 2010 (Hassler et al., 2014); 3) an axenic laboratory culture of the haptophyte Phaeocystis antarctica; and 4) an axenic laboratory culture of the coccolithophorid Emiliania huxleyi. P. antarctica and E. huxleyi were selected as both are major bloom forming species in the Southern Ocean that contribute to oceanic carbon export (Di Tullio et al., 2000). Both species have also been shown to produce exudates in response to Fe addition that are rich in polysaccharides (Aluwihare and Repeta, 1999, Boye and van den Berg, 2000).

\section{Materials and methods}

\subsection{Isolation and characterization of bacterial and algal EPS}

\subsubsection{Growth of bacterial culture and EPS Isolation}

The bacterial strain CAM025 (Pseudoalteromonas sp.) was isolated from Antarctic sea ice and phenotypically characterized as described previously (Mancuso Nichols et al., 2005). The strain was grown in marine broth (MB+Glc) composed of $1 \mathrm{~g} \mathrm{~L}^{-1}$ yeast extract (Oxoid Ltd.); $3 \mathrm{~g} \mathrm{~L}^{-1}$ bacteriological peptone (Oxoid Ltd.); $35 \mathrm{~g} \mathrm{~L}^{-1}$ artificial sea salts (Sigma); $4.76 \mathrm{~g} \mathrm{~L}^{-1}$ HEPES (Sigma, pH adjusted to 8.0). A glucose (BDH Chemicals) solution was prepared and autoclaved separately before being combined with the above media for a final concentration of $3 \%$ glucose (w/v). One litre polycarbonate baffled flasks containing $500 \mathrm{~mL} \mathrm{MB}+\mathrm{Glc}$ were inoculated with $50 \mathrm{~mL}$ of the exponentially growing batch cultures of the bacterial isolate. Cultures were incubated in an oscillating water bath (Ratek Pty Ltd, Australia) at $10^{\circ} \mathrm{C}$. The purity of the cultures was confirmed by subculturing onto marine agar (MA+Glc) growth media composed of the MB+Glc with $15 \mathrm{~g} \mathrm{~L}^{-1}$ agar (Difco Bacto Laboratories). For subsequent isolation and purification, cell growth in the culture broth was stopped by the addition of sodium azide $\left(\mathrm{NaN}_{3}, 0.4 \mathrm{~g} \mathrm{~L}^{-1}\right.$, Sigma). The culture was diluted with three volumes of sterile artificial sea salts in distilled water (3.5\% w/v, $\mathrm{pH} 8.0)$ prior to centrifugation (30000 g, $2 \mathrm{~h}, 4^{\circ} \mathrm{C}$, Sorvall RC 26 Plus). The supernatant was pressure-filtered through glass fiber filters (GF/F, Whatman) prior to ultrafiltration to isolate the EPS. Culture filtrates were diafiltered with 10 volumes of sterile Milli- $\mathrm{Q}^{\mathrm{TM}}$ water and concentrated at room temperature (VivaFlow 200 ultrafiltration unit, PES membrane, 100 KDa MWCO, Sartorius). The concentrated (50 mL) EPS solutions were frozen overnight and the water was removed by freeze-drying (Dynavac). 


\subsubsection{Growth of phytoplankton cultures.}

The Prymnesiophyceae Phaeocystis antarctica (CS 243, Prydz Bay, Antarctica) and Emiliania huxleyi (CS 812, Mercury Passage, Tasmania, Australia) from the Australian National Algal Culture Collection were used to isolate phytoplanktonic EPS. Cultures were maintained in $0.2 \mu \mathrm{m}$ filtered seawater collected in the Sub-Antarctic Zone (SAZ-Sense voyage, RV Aurora Australis, $1531^{\circ} \mathrm{E} 453^{\circ} \mathrm{S}$, 11th Feb. 2007; Bowie et al., 2011). To achieve sufficient biomass the filtered seawater was enriched with micronutrients (Fe, Zn, Co $=5 \mathrm{nM}, \mathrm{Cu}$ and $\mathrm{Ni}=2 \mathrm{nM}$, Se $=1 \mathrm{nM}$, all presumed to be buffered by natural ligands present), chelexed macronutrients $\left(\mathrm{NOx}=30 \mu \mathrm{M}, \mathrm{PO}_{4}=2 \mu \mathrm{M}, \mathrm{Si}=30 \mu \mathrm{M}\right)$ and vitamins (as per media F/20). P. antarctica was maintained at $2.5^{\circ} \mathrm{C}$ under $55 \mu$ moles photons $\mathrm{m}^{-2} \mathrm{~s}^{-1}$ whereas E. huxleyi was maintained at $20^{\circ} \mathrm{C}$ under $150 \mu$ moles photons $\mathrm{m}^{-2} \mathrm{~s}^{-1}$ under a $12 \mathrm{~h}: 12$ h light:dark cycle. In order to isolate EPS, 11 L cultures were grown to stationary phase (10 days) prior to filtration under laminar flow using filters (GF/C or precombusted GF/934-AH glass fiber filters, Whatman, 1.2-1.5 $\mu \mathrm{m}$ ) pre-rinsed with $0.5 \mathrm{M}$ quartz distilled $\mathrm{HCl}$ (Seastar) and Milli- $\mathrm{Q}^{\mathrm{TM}}$ water to minimise the introduction of metals leached from the filters. Glass fiber filters were used in preference to polycarbonate filters as they assisted with the breaking up of $P$. antarctica colonies, whilst leaving the cells intact, and allowed for a greater quantity of EPS to be collected. As such, the isolated EPS contained both exuded EPS and that associated with the mucus from the colony. Filters were stored at $-20^{\circ} \mathrm{C}$ for further fatty acid analysis to check for bacterial contamination and POC analysis (Table S1). The filtrate, containing EPS, was collected into a clean carboy to which $4 \mathrm{~g}$ of $\mathrm{NaN}_{3}$ was added (Sigma) to avoid bacterial growth and kept at $4^{\circ} \mathrm{C}$ in the dark until ultrafiltration. Growth data for $P$. antarctica and E. huxleyi are provided as supplementary information (Table S1; Fig. S1).

The natural phytoplankton community was sampled at the depth of the fluorescence maximum in the Sub-Antarctic Zone (P3) during the PINTS voyage (RV Southern Surveyor, Jan-Feb. 2010; Hassler et al., 2014). Water used in experiments was sampled using noncontaminating procedures as per GEOTRACES recommendation using a Teflon double diaphragm pump (Wilden A100 with Teflon fittings) and acid-cleaned PE tubing which was set up to deliver water in the clean room container under a laminar HEPA filter (ISO Class 5). Water was left to run for approximately $30 \mathrm{~min}$ to rinse the hose prior collecting water through an acid washed $0.2 \mu \mathrm{m}$ filter cartridge (Acropak 100, PALL, $0.2 \mu \mathrm{m}$ with $0.8 \mu \mathrm{m}$ pre-filter). Filtered seawater was collected in acid-washed polycarbonate carboys under a 
HEPA filter (ISO Class 5) and stored at $4{ }^{\circ} \mathrm{C}$ in the dark for 5 days prior to addition of $\mathrm{NaN}_{3}$ and ultrafiltration.

\subsubsection{Isolation of EPS from cultured phytoplankton and natural seawater.}

The ultrafiltration system (Labscale TFF system, 10 KDa MWCO PES membrane, Pellicon R XL 50 Cassette, Millipore) used to isolate the EPS was prepared by rinsing with $0.1 \mathrm{M} \mathrm{HCl}$ for $3 \mathrm{~h}$ and then with Milli- $\mathrm{Q}^{\mathrm{TM}}$ water until the $\mathrm{pH}$ of the permeate was that of Milli- $\mathrm{Q}^{\mathrm{TM}}$. Phytoplankton culture filtrates and seawater were diafiltered against Milli- $\mathrm{Q}^{\mathrm{TM}}$ water until the conductivity was no more than $5 \times$ that of Milli- $\mathrm{Q}^{\mathrm{TM}}$. The retenate was then concentrated to $100 \mathrm{~mL}$, frozen and freeze dried prior to weighing. The EPS yield was between 4.9 and $5.7 \mathrm{fg}$ EPS per cell for both algal strains (Table S1).

\subsection{Analytical procedures}

\subsubsection{Crude chemical composition of EPS.}

The EPS were dissolved in Milli-Q ${ }^{\mathrm{TM}}$ water $\left(1 \mathrm{mg} \mathrm{mL}^{-1}\right)$ and used for subsequent colorimetric assays. Uronic acid, protein, and total neutral carbohydrate content of the EPS was determined as per Mancuso Nichols et al. (2005) using the meta-hydroxydiphenyl method for uronic acid analysis (std: D-glucuronic acid, Sigma), bicinchoninic acid (BCA) protein assay for protein analysis (std: bovine serum albumin, Sigma) and the orcinol-sulfuric acid method for neutral carbohydrate analysis (std: D-glucose, Sigma). Detections limits for the methods were $25 \mathrm{mg}$ glucuronic acid eq. $\mathrm{L}^{-1}, 100 \mathrm{mg}$ protein $\mathrm{L}^{-1}$, and $100 \mathrm{mg}$ glucose eq. $\mathrm{L}^{-1}$ respectively.

Total saccharide concentration was determined semi-quantitatively as per Myklestad et al. (1997). The total sugar concentration ( $\mu \mathrm{mol} \mathrm{C} \mathrm{L}{ }^{-1}$ ) was determined from a standard curve prepared from D-glucose in Milli- $\mathrm{Q}^{\mathrm{TM}}$ water. The detection limit of the method was $0.07 \mathrm{mg}$

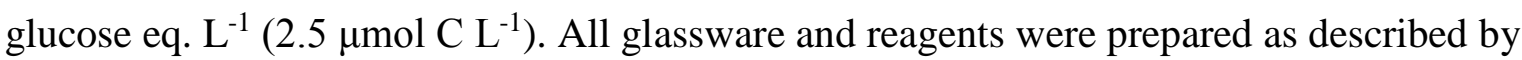
(Myklestad et al., 1997).

Analysis for heme signatures was performed using the LC-MS method of Gledhill (2014). The detection limit of the method at analytical dilution was $1.2 \mathrm{fmol} \mathrm{L}^{-1}$ and calculated 
detection limits g $^{-1}$ EPS were; Sea ice bacterial EPS $=1.11 \mathrm{nmol}$; SAZ bloom EPS $=0.433$ nmol; P.antarctica $=1.01$ nmol; E. huxleyi $=0.436 \mathrm{nmol} \mathrm{g}^{-1}$ EPS.

\subsubsection{EPS fractionation and molar mass determination}

Physico-chemical characterisation of the bacterial and algal EPS were analyzed using asymmetrical flow field-flow fractionation (AFIFFF; AF2000 Focus, Postnova Analytics) coupled with a diode array detector (UV), refractive index detector (RI) and inductively coupled plasma mass spectrometry detector (ICP-MS, Agilent, 7700x). System control and data collection was performed using the AFIFFF2000 Control software (version 1.1.011, Postnova Analytics) for RI and the LC solution workstation software (Shimadzu) for UV. The EPS samples were resuspended in Milli- $\mathrm{Q}^{\mathrm{TM}}$ water to attain a concentration of $0.3 \mathrm{mg} \mathrm{L} \mathrm{L}^{-1}$ and were then passed through $0.45 \mu \mathrm{m}$ filters (syringe filters, Millopore) prior to injection into the system via a $1 \mathrm{~mL}$ sample loop. Trapezoidal channels of $350 \mu \mathrm{m}$ thickness with 10 kDa cut-off regenerated cellulose membrane (RC, Postnova Analytics) were utilized and a carrier solution of $100 \mathrm{mM} \mathrm{NH}_{4} \mathrm{NO}_{3}$ was used (Fluka, $\mathrm{pH}$ 6.0, pre-filtered through $0.1 \mu \mathrm{m}$ Teflon filters Postnova analytics). Injection (focusing time $=10 \mathrm{~min}$; inlet flow rate of 0.2

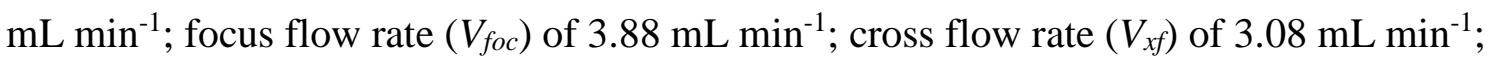

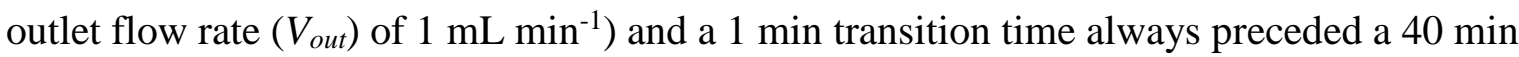
elution step. Two different elution procedures were used during this study; the first consisted of a linear cross flow gradient starting from $3 \mathrm{~mL} \mathrm{~min}^{-1}$ and ending at $0 \mathrm{~mL} \mathrm{~min}{ }^{-1}$ and for the second a constant cross flow of $0.2 \mathrm{~mL} \mathrm{~min}^{-1}$ was applied. Each run was finished by a washing step of $10 \mathrm{~min}$ where no cross flow was applied $\left(V_{x f}=0 \mathrm{~mL} \mathrm{~min}{ }^{-1} ; V_{\text {out }}=1 \mathrm{~mL} \mathrm{~min}{ }^{-1}\right)$. For gradient $V_{x f}$, EPS molar masses $\left(M_{W}\right)$ were calculated from a calibration curve of the log retention time vs $\log M_{W}$ (Reszat and Hendry, 2005) using $1 \mathrm{~mL}$ of $5 \mathrm{mg} \mathrm{L}^{-1}$ polystyrenesulfonates standards injections (PSS, Postnova Analytics; $M_{W}$ ranged from 1.36 to $979 \mathrm{kDa})$. Molar mass dispersity $\left(\bigoplus_{\mathrm{M}}\right)$, a measure of the spread of the molar mass distribution in a sample, was also derived (Stepto, 2009);

$$
\bigoplus_{\mathrm{M}}=M w / M n
$$

where $M w$ is the weight average molar mass and $M n$ the number average molar mass. In addition the molar mass at maximum peak intensity $(M p)$ was measured.

For comparison and discussion, the EPS colloidal distribution using these protocols was arbitrarily separated in three main pools of molar mass: 1) low molar mass components 
(LMM) from 0 to $300 \mathrm{kDa}$; 2) intermediate molar mass components (IMM, from 300 to 800 $\mathrm{kDa}$ ); 3) high molar mass components (HMM) from 800 to $945 \mathrm{kDa}$ plus any colloids $>945$ $\mathrm{kDa}$ that eluted rapidly once the cross flow was stopped.

For the constant $V x f=0.2 \mathrm{~mL} \mathrm{~min}^{-1}$ that was able to resolve larger compounds, colloid hydrodynamic radii $\left(R_{h}\right)$ were evaluated using the elution theory as developed by Schimpf and co-authors (2000). The ${ }^{56} \mathrm{Fe}$ signal was monitored using an ICP-MS (Agilent 7700x, He collision cell) connected to the AFIFFF outflow using a two channeled peristaltic pump, the first channel carrying the sample and the second an internal standard of $\mathrm{Rh}$ at $1 \mathrm{ppb}$ in $4 \%$ $\mathrm{HNO}_{3}$ (Backer suprapur). The two channels were connected to a mixing chamber before final sample introduction to the ICP instrument. In order to simplify the visualization of the comparison between the RI, UV and Fe signals, these were normalized to the values obtained at maximum peak intensities for each EPS analyzed.

\subsubsection{Trace element and macronutrient analysis.}

Trace element concentrations ( $\mathrm{Al}, \mathrm{Cd}, \mathrm{Co}, \mathrm{Cu}, \mathrm{Fe}, \mathrm{Mn}, \mathrm{Pb}, \mathrm{Zn}$ ) in EPS solutions (EPS in ultra-pure water) were determined using Sector Field Inductively Coupled Plasma Mass Spectrometry (Thermo Fisher ELEMENT 2, Bremen, Germany). Measurements were made using both low and medium resolution modes (nominally $\mathrm{m} / \mathrm{dm} \sim 400$ for ${ }^{111} \mathrm{Cd},{ }^{208} \mathrm{~Pb} ; \mathrm{m} / \mathrm{dm}$ $>4000$ for ${ }^{27} \mathrm{Al},{ }^{55} \mathrm{Mn},{ }^{56} \mathrm{Fe},{ }^{59} \mathrm{Co},{ }^{63} \mathrm{Cu},{ }^{66} \mathrm{Zn}$ ). The use of increased spectral resolution allowed for essentially interference free analysis. Potential sample matrix effects associated with the analysis of EPS containing samples were minimized through sample dilution, with indium added as an internal standard. Premixed external calibration standards (QCD Analysts, MISA suite of solutions, Spring Lake, USA) were used for instrument calibration. A similar analytical protocol has been reported by Bowie et al. (2010). Samples were analyzed under standard laboratory and instrument conditions. Indicative detection limits for these analyses were; $\mathrm{Al}=0.11 \mathrm{nM}, \mathrm{Cd}=0.02 \mathrm{nM}, \mathrm{Co}=0.03 \mathrm{nM}, \mathrm{Cu}=1.6 \mathrm{nM}, \mathrm{Fe}=0.36$ $\mathrm{nM}, \mathrm{Mn}=0.07 \mathrm{nM}, \mathrm{Pb}=0.09 \mathrm{nM}$ and $\mathrm{Zn}=3.0 \mathrm{nM}$. Detection limits, calculated as nmol $\mathrm{g}^{-1}$ EPS, are presented in table S3.

Macronutrient concentrations (nitrate + nitrite $\left(\mathrm{NO}_{\mathrm{X}}\right)$, nitrite $\left(\mathrm{NO}_{2}\right)$, ammonia $\left(\mathrm{NH}_{3}\right)$, and phosphate $\left(\mathrm{PO}_{4}\right)$ ) were determined by standard colorimetric methodology (Grasshoff et al. 1983) as adapted for flow injection analysis (FIA) on a 4 channel LACHAT Instruments 
Quick-Chem 8500 autoanalyser (Hales et al. 2004). Indicative detection limits for these analyses were; $\mathrm{NO}_{\mathrm{X}}$ and $\mathrm{NO}_{2}=0.2 \mu \mathrm{M}, \mathrm{NH}_{3}=0.3 \mu \mathrm{M}, \mathrm{PO}_{4}=0.1 \mu \mathrm{M}$. Detection limits, calculated as nmol g-1 EPS, are presented in table S3.

\subsubsection{Chemical speciation of Fe-organic ligand complexes.}

Fe speciation was measured by Competitive Ligand Exchange-Adsorptive Cathodic Stripping Voltammetry (CLE-AdCSV) following the method of Croot and Johannson (2000). The instruments used were $\mu$ Autolab II and III potentiostat (Ecochemie, Netherlands) with a hanging mercury drop electrode (HMDE drop size 2, $0.4 \mathrm{~mm}^{2} \pm 10 \%$, Metrohm VA 663 stand), a glassy carbon rod counter electrode, and a double junction Ag/AgCl reference electrode with a salt bridge filled with $3 \mathrm{M} \mathrm{KCl}$. The instruments were controlled using GPES software, version 4.7. Samples were prepared in $0.2 \mu \mathrm{m}$ filtered Tasman Sea surface seawater (seawater; GP13 GEOTRACES voyage, RV Southern Surveyor, May-June 2011, 30 $00{ }^{\circ} \mathrm{S} 16700^{\circ} \mathrm{E}$ ) collected using non-contaminating procedures as recommended by the GEOTRACES program. A sufficient volume of EPS was added to the seawater to provide 1 $\mathrm{nM}$ dFe in addition to the $0.56 \mathrm{nM}$ (measured by ICP-MS) already present in the seawater (final concentration $=1.56 \mathrm{nM}$ ).

The solutions were equilibrated at $4^{\circ} \mathrm{C}$ in the dark for either $24 \mathrm{~h}$ or $9 \mathrm{wk}$ (as per Hassler et al., 2011a). After equilibration, the EPS enriched seawater was bought to ambient temperature and dispensed into $10 \mathrm{~mL}$ polypropylene tubes to which inorganic Fe was added (1 $\mu \mathrm{M}$ standard prepared daily; $\mathrm{Fe}$ as $\mathrm{FeCl}_{3}$ in $0.5 \mathrm{M} \mathrm{HCl}$, ICP grade, Fluka). The solution was then buffered to $\mathrm{pH} 8.1$ using $50 \mu \mathrm{L}$ of $1 \mathrm{M}$ EPPS (SigmaUltra) in $0.3 \mathrm{M} \mathrm{NH} 4 \mathrm{OH}$ (Seastar, Baseline ${ }^{\circledR}$ ). After a further 2 h equilibration at ambient temperature in the dark, 10 $\mu \mathrm{M}$ of the exchange ligand 2-(2-Thiazolylazo)-p-cresol, TAC, (Sigma batch 09326TH; 0.01 M dissolved in triple quartz distilled methanol, Mallinkrodt HPLC grade, prepared fortnightly) was added and the samples equilibrated for a further 18 to $20 \mathrm{~h}$ (ambient temperature, dark; as per Hassler et al., 2011a). A total of 24 titration samples were prepared using an Fe concentration range of 0-16 nM. Samples were analysed in polycarbonate titration cells and stirred continually (save for a period of quiescence when measuring) with an inbuilt PTFE rod (1500 rpm). Dissolved oxygen was purged from the sample for $240 \mathrm{~s}$ using high purity argon (Air Liquide), followed by $120 \mathrm{~s}$ deposition time onto the Hg drop. Labile Fe (Fe labile$_{\text {en }}$, defined as the proportion of Fe that is exchangeable with the TAC over the experimental conditions, was calculated from the speciation data, and concentrations and 
conditional stability constants (log $\mathrm{K}_{\mathrm{Fe}}{ }^{\mathrm{L}}$ ) of the $\mathrm{Fe}^{\prime}$-binding ligands present were determined using the non-linear fit method of Gerringa et al. (1995). As a quality control of the data presented, the non-linear fit method was checked to be within $10 \%$ of the data using a linearization method (van den Berg, 1982). A conditional side reaction coefficient $\left(\alpha_{\mathrm{Fe}^{\prime}}(\mathrm{TAC}) 2\right)$ of $627 \pm 72(10 \mu \mathrm{M}$ TAC) was used for calculations, determined using UV-oxidised $0.2 \mu \mathrm{m}$ filtered Southern Ocean water in the presence of $10 \mathrm{nM}$ inorganic Fe and diethylenetriaminepentaacetic acid (DTPA, Sigma) and using non-linear fit as per Croot and Johannson (2000) and Hassler et al. (2013). Analysis of the $0.2 \mu \mathrm{m}$ filtered seawater used revealed that the organic ligands naturally present did not significantly affect the results obtained for the EPS as these were three to seven fold lower in concentration and had a weak conditional stability constant in respect of Fe'-binding when compared to the EPS experimental treatments. The detection limit was $0.05 \mathrm{nM}$ Fe as determined from three times the standard deviation of repeated measurements of a Southern Ocean seawater sample $(n=8$ for both instruments). Errors for ligand concentrations and conditional stability constants from the non-linear fit method were calculated using solver (Excel 2010) as per the "jacknife" procedure (Harris, 1998).

\subsubsection{Fe size fractionation and solubility}

Experimental solutions consisted of $0.2 \mu \mathrm{m}$ filtered Tasman Sea surface water (as for section 2.2.4) spiked either with inorganic ${ }^{55} \mathrm{FeCl}_{3}$ (stock solution as ${ }^{55} \mathrm{FeCl}_{3}$ in $0.5 \mathrm{M} \mathrm{HCl}$; Perkin Elmer, $22.36 \mathrm{mCi} \mathrm{mg}^{-1} \mathrm{Fe}$ at the time of use) or ${ }^{55} \mathrm{Fe}$-EPS. One hundred fold concentrated stock solutions of ${ }^{55} \mathrm{Fe}$ and EPS were allowed to reach equilibrium for 1 week prior to being spiked into the experimental solutions. EPS concentration was fixed across the experimental solutions at a concentration that gave $1 \mathrm{nM}$ Fe as background concentration, whereas the total Fe concentration added ranged from 0.3 to $12 \mathrm{nM}$ (either as ${ }^{55} \mathrm{FeCl}_{3}$ or ${ }^{55} \mathrm{Fe}-\mathrm{EPS}$ ).

Considering background Fe concentrations in the synthetic seawater (measured at $0.6 \mathrm{nM}$ for this batch) and EPS and a $0.3 \mathrm{nM}{ }^{55} \mathrm{Fe}$ minimum addition, the first experimental observation was at $1.9 \mathrm{nM}$ total Fe. The samples were then incubated for $24 \mathrm{~h}$ at $4^{\circ} \mathrm{C}$ in the dark. This low temperature was used as these experiments were run in parallel with bioavailability experiments using the Antarctic diatom Chaetoceros simplex (Hassler et al., this issue). Samples were then size-fractionated and collected as $0.2 \mathrm{um}$ and $0.02 \mathrm{um}$ filtrates $(0.2 \mu \mathrm{m}$ polycarbonate syringe filters, Millipore; $0.02 \mu \mathrm{m}$ Anatop syringe filters, Whatman). $10 \mathrm{~mL}$ of scintillation cocktail was added (Ultima Gold, Perkin Elmer) to the radiolabeled solutions and 
the samples were analyzed using a liquid scintillation counter (Perkin Elmer, Tricarb 2810). Counts per minute were transformed into disintegrations per minute (dpm) using a custom made quench curve $\left(r^{2}=0.93, n=10\right)$, dpm were expressed at the time of reference from the source using the exponential decay of ${ }^{55} \mathrm{Fe}$. Dpm were then converted into concentrations using total initial radioactivity and $\mathrm{dFe}$ concentrations. The quench curve was made under similar conditions to the experiments; in this case in a total volume of $2 \mathrm{~mL}$ (including seawater, increasing volumes of the quenching agent $(0-200 \mu \mathrm{l})$, and a fixed ${ }^{55} \mathrm{Fe}$ volume) in presence of $10 \mathrm{~mL}$ scintillation cocktail. The comparison between three size fractions (total (initial added Fe) $<0.2 \mu \mathrm{m},<0.02 \mu \mathrm{m}$ ) were used to calculate the percentage of the Fe present in the soluble (operationally defined as Fe present in the $0.02 \mu \mathrm{m}$ filtered fraction) and colloidal pool. Colloidal Fe was operationally defined as any Fe present between 0.02 and $0.2 \mu \mathrm{m}$ size fraction. As particulate Fe was not directly measured a mass balance calculation could not be performed in our study. It is to be noted that the EPS concentration associated with a $1 \mathrm{nM}$ dFe used here corresponded to 2.6, 0.4, 0.1, and $0.2 \mathrm{mg} \mathrm{L}^{-1}$ EPS for EPS from sea-ice bacteria, SAZ bloom, P. antarctica and E. huxleyi, respectively. Experiments were run in duplicate.

\subsubsection{Determination of $\mathrm{Fe}(\mathrm{II})$ oxidation rates in the presence of natural bacterial and algal} EPS and model saccharides.

Fe(II) oxidation rates were determined with UV-visible spectroscopy using the ferrozine (FZ) method. Although FZ has been shown to slowly promote the reduction of $\mathrm{Fe}(\mathrm{III})$ to $\mathrm{Fe}$ (II) (Hudson et al., 1992; Murray and Gill, 1978) it does not bind Fe(III) to a significant degree (Pullin and Cabaniss, 2003) and reacts extremely rapidly with Fe(II) (Lin and Kester, 1992; Thompsen \& Mottola, 1984). The purple complex formed, $\mathrm{Fe}^{\mathrm{II}} \mathrm{FZ}_{3}$, is stable at $\mathrm{pH} 8.0$ and has a maximum absorbance at $562 \mathrm{~nm}$ (Stookey, 1970; Viollier et al., 2000). A $50 \mathrm{mM}$ stock solution of 3-(2-pyridyl)-5-6-diphenyl-1,2,4-triazine-4',4”disulfonic acid sodium salt (ferrozine; Fluka analytical) was prepared by dissolving in ultra-pure water. From this a 1 $\mathrm{mM}$ working solution was prepared daily in synthetic seawater and the $\mathrm{pH}$ adjusted to 8.09 to match the $\mathrm{pH}$ of the natural seawater used to prepare the samples. A working stock solution of $150 \mu \mathrm{M}$ Fe(II) (as ammonium iron(II) sulfate hexahydrate, Ajax Chemicals) was prepared daily in $2 \mathrm{mM} \mathrm{HCl}$. This $\mathrm{pH}$ was sufficient to prevent Fe(II) oxidation yet low enough to prevent significant $\mathrm{pH}$ change in the samples $(\leq 0.02 \mathrm{pH}$ units) that could affect rate measurements. Adjustments to $\mathrm{pH}$ were made using ultra-pure $\mathrm{NaOH}$, and $\mathrm{pH}$ was measured 
using a Hanna 9025 microprocessor $\mathrm{pH}$ meter combined with a glass electrode and $\mathrm{Ag} / \mathrm{AgCl}$ reference, calibrated daily using NBS scale NIST-traceable buffer solutions ( $\mathrm{pH} 7.01,10.01$ ). During the period of analysis, the $\mathrm{pH}$ of the samples and reagents remained within $\pm 0.02 \mathrm{pH}$ units.

EPS from the sea ice bacteria, SAZ bloom, E. huxleyi, or a model ligand in the form of dextran (DEX; polysaccharide) or glucuronic acid (GLU; monosaccharide) was added to seawater to provide an Fe to ligand ratio (Fe:L) of 1:1.66. The volume of EPS used was based on the concentration of Fe-binding ligands measured by CLE-AdCSV and the excess of these ligands present in respect of Fe in the EPS. To investigate the effect of the concentration of organic ligands on a fixed concentration (30 nM) of Fe(II), samples containing DEX and GLU at Fe:L ratios from 1:1.66 to 1:166 were prepared. Enriched samples were equilibrated for 18 to $24 \mathrm{~h}$ at $4^{\circ} \mathrm{C}$ in the dark. After equilibration the samples were brought to ambient temperature $\left(22^{\circ} \mathrm{C}\right)$ before analysis, or maintained at $4^{\circ} \mathrm{C}$ by placing the sample in a bath of ice and water. Immediately prior to analysis Fe(II) (30 nM ) was added to the sample which was then mixed with the FZ at a $\mathrm{T}$ junction prior to being driven through a $1.0 \mathrm{~m}$ path length cell (“waveguide”, (LWCC Type II, World Precision Instruments) by a peristaltic pump. The resulting $\mathrm{Fe}^{\mathrm{II}} \mathrm{FZ}_{3}$ complex was measured colorimetrically at $562 \mathrm{~nm}$ using Ocean Optics spectrophotometry. The detection limit of the instrument at both $22^{\circ} \mathrm{C}$ and $4{ }^{\circ} \mathrm{C}$ was $1 \mathrm{nM}$ $\mathrm{Fe}(\mathrm{II})$ calculated as three times the standard deviation of the lowest calibration standard $(n=$ 6; $10 \mathrm{nM} \mathrm{Fe(II)).} \mathrm{Samples} \mathrm{were} \mathrm{prepared} \mathrm{in} \mathrm{triplicate} \mathrm{in} 0.2 \mu \mathrm{m}$ filtered Tasman Sea surface water (seawater). Statistical differences of added organic material from unamended $0.2 \mu \mathrm{m}$ filtered seawater were determined using an unpaired t-test.

\subsubsection{Analysis of Fe-binding humic substance-like material}

As it was expected that the concentration of Fe-binding humic substance-like (HS-like) material would be very low, samples were prepared in synthetic seawater (As per Price et al., 1989) rather than $0.2 \mu \mathrm{m}$ filtered seawater to remove any interference from HS-like substances that were originally present. Determination of HS-like material was made using the voltammetric method of Laglera et al. (2007) (Instrumentation as per section 2.2.4). Briefly, $750 \mu \mathrm{L}$ of a mixed reagent solution of the oxidant $\mathrm{KBrO}_{3}$ (0.4 M Sigma), buffer EPPS (0.2 M, Sigma), and $\mathrm{NH}_{4} \mathrm{OH}(0.2 \mathrm{M})$ was added to $10 \mathrm{~mL}$ of sample in the presence of $50 \mathrm{nM}$ inorganic Fe (final $\mathrm{pH}$ 8.2). Samples were equilibrated at ambient temperature for $1 \mathrm{~h}$ and then analysed using 250 s purge time and 300 s deposition time. Standard addition of 
Suwannee River Fulvic Acid (SRFA, International Humic Substances Society, standard 1) in increments of $0.02 \mathrm{mg} \mathrm{L}^{-1}$ from a $15.75 \mathrm{mg} \mathrm{L}^{-1}$ working stock (prepared weekly and stored at $4^{\circ} \mathrm{C}$ in the dark) was used to determine the concentration of HS-like material ([HS-like]) in the samples. The detection limit of the instruments was $1.56 \mu \mathrm{g} \mathrm{L}^{-1}$ determined from three times the standard deviation of 10 repeated measurements of a Southern Ocean seawater sample.

\subsection{Experimental precautions.}

All plasticware (LDPE and HDPE bottles, pipette tips, and polycarbonate materials) were cleaned by first soaking in detergent (Citrinox acid detergent, 5\% v/v) for $24 \mathrm{~h}$, followed by rinsing five times in deionised water. The plasticware was then soaked for four weeks in $1 \mathrm{M}$ $\mathrm{HCl}$, except for polycarbonate which was soaked for one week to avoid deterioration. The equipment was then rinsed seven times in ultra-pure water and dried in a laminar flow hood (ISO class 5). All trace metal clean items were sealed in triple bags until use and experimental samples were sealed in triple bags during equilibration/incubation periods. All sample manipulations and reagent preparation was carried out under a laminar HEPA filter (ISO class 5). All reagents were made up in ultra-pure water unless otherwise stated. The EPPS buffer used in the Fe chemical speciation analysis (section 2.2.4) and $\mathrm{KBrO}_{3}$ reagent used for the HS-like analysis (section 2.2.7) were passed through Chelex-100 resin (BioRad, conditioned as per Price et al., 1989) prior to use to minimize Fe contamination.

\section{Results}

\subsection{Functional composition of EPS.}

All EPS isolates contained protein, uronic acid, neutral sugars and saccharides in varying proportions (Table 1). The bacterial EPS was composed primarily of neutral sugars, with a small proportion of uronic acid, and comparatively little protein (Table 1). The composition of the two cultured algal isolates, P. antarctica and E. huxleyi, were very similar in terms of the relative concentration (\%) of protein, uronic acid and neutral sugar content, however, the concentration of total saccharides in the P. antarctica EPS was 1.6-fold higher than that measured in the E. huxleyi EPS (Table 1). The SAZ bloom, which was dominated by coccolithophorids but contained a mixed algal and bacterial community, had the lowest relative or measured concentration of all constituents, with the relative concentrations of 
protein, uronic acid and neutral sugars being approximately half that of the two cultured algal isolates (Table 1).

\subsection{Molar mass and size distribution of EPS.}

Because EPS are known to be polydisperse in size, two different cross flow conditions were used to characterize their molar mass or size distributions. The first involved a linear cross flow gradient starting from $3 \mathrm{~mL} \mathrm{~min}^{-1}$. Under such conditions, components of molar masses below $800 \mathrm{kDa}$ can be characterized (as defined by PSS calibration, Fig 1). For the second, a constant cross flow of $0.2 \mathrm{~mL} \mathrm{~min}^{-1}$ was applied and focused on colloids having hydrodynamic radii $\left(R_{h}\right)$ below $100 \mathrm{~nm}$ (as defined by the theory, Fig. 2).

For gradient cross flow conditions (starting from $V x f=3 \mathrm{~mL} \mathrm{~min}^{-1}$ ), the refractive index (RI) fractograms obtained showed that the sea ice bacterial EPS was predominantly made up of HMM components (Fig 1A). By contrast the algal EPS isolates from P. antarctica and E. huxleyi (Fig 1B and C) cultures and the EPS isolated from the SAZ bloom (Fig 1D) comprised mainly LMM material. The EPS isolated from E. huxleyi also contained a very small amount of IMM material at around $750 \mathrm{kDa}$ (Fig.1C).

Mass distribution parameters were calculated for the LMM region in all algal isolates (Table 2) which revealed number average molar masses $(M n)$ of $19 \mathrm{kDa}$ for $P$. antarctica, $15 \mathrm{kDa}$ for E. huxleyi, and $24 \mathrm{kDa}$ for the SAZ bloom. Molar mass dispersity ( $\left.\bigoplus_{\mathrm{M}}\right)$ was close to 2 in all cases indicating a heterogenic distribution (Table 2).

UV fractograms followed the same trend as the RI fractograms. The maximum peak intensity $(\mathrm{Mp})$ measured for both $P$. antarctica and E. huxleyi were low at $\sim 8 \mathrm{kDa}$ (Table 3, UV). In the SAZ bloom two peaks were identified (Fig.1D), the first with a similar molar mass to the two algal EPS of $\sim 8 \mathrm{kDa}$ and the second giving a $M p$ of $24 \mathrm{kDa}$.

In the P. antarctica and SAZ bloom EPS the Fe distribution also followed the LMM trend of the RI with the $M p$ giving molar masses of $\leq 20$ (Fig.1B and D, Table 2). The distribution of Fe in the E.huxleyi EPS was more complex as both LMM and HMM components appeared to have equivalent proportions of Fe bound to them (Fig. 1C). A further peak was observed in the IMM region which, despite giving a much lower signal intensity, was not of negligible proportions. 
Using a constant cross flow (Fig. 2) the Fe distributions for the sea ice bacteria and $P$. antarctica EPS followed the trends of RI and UV absorbance very well. The E. huxleyi and SAZ bloom EPS were less well matched in all parameters but a good general agreement was still observed. In the sea ice bacterial EPS the Fe appeared to be associated with EPS components of similar optical characteristics and homogenously distributed across components with a hydrodynamic radii $\left(R_{h}\right)>10 \mathrm{~nm}$ with a maximum Fe peak intensity at 29 nm (Fig. 2A). This high molar mass pattern (unfractionated when using the first elution protocol) obtained for bacterial EPS was also correlated to the presence of scattered light measured by MALS (Multi Angle Light Scattering, not shown). Deconvolution where three main components with $R_{h}$ of $26 \mathrm{~nm}, 40 \mathrm{~nm}$ and $60 \mathrm{~nm}$ at peak maximums were used gave the best fit of the Fe signal (originLab software, Fig. S2). Such in silico deconvolution could, however, not account for the complexity of EPS molecular assemblages and should be viewed with caution. The EPS isolated from P. antarctica and E. huxleyi cultures and the SAZ bloom were dominated by components with $R_{h}$ of $<10 \mathrm{~nm}$ (Fig. 2B, C, D), a result reinforced by the absence of strong scattered light over the elution (not shown). However, there was a small proportion of Fe associated with components of $R_{h} 10$ to $70 \mathrm{~nm}$ present in the E. huxleyi EPS (Fig. 2C). Overall the results obtained using the two different fractionation protocols were consistent.

\subsection{Trace element and macronutrient composition of EPS}

Amongst the trace elements analyzed by ICP-MS Fe was most abundant (Table S2). Except for Co in the E. huxleyi EPS and Cu in the P. antarctica EPS, all EPS were also associated with $\mathrm{Al}, \mathrm{Co}, \mathrm{Cu}, \mathrm{Mn}$ and $\mathrm{Zn}$ (Table S2). In addition, the algal EPS isolates (SAZ bloom, $P$. antarctica and E. huxleyi) were also associated with toxic ( $\mathrm{Pb}, \mathrm{Cd})$ trace metals, although concentrations were highly variable between isolates (Table S2). Measured concentrations of $\mathrm{Al}$ and $\mathrm{Mn}$ and the more toxic metals $\mathrm{Pb}$ and $\mathrm{Cd}$ were substantially higher in the natural SAZ bloom EPS than all other algal EPS isolates (Table S2).

Macronutrients $\left(\mathrm{NO}_{\mathrm{X}}, \mathrm{NO}_{2}, \mathrm{NH}_{3}\right.$ and $\left.\mathrm{PO}_{4}\right)$ were present in variable concentrations in all EPS isolates (bacterial and algal), with $\mathrm{NH}_{3}$ being the dominant form of $\mathrm{N}$ present. (Table S2). Of the algal isolates, $P$. antarctica contained the highest concentrations of all macronutrients, except for $\mathrm{NO}_{2}$, and the SAZ bloom the lowest (Table S2). 


\subsection{Effect of EPS on Fe biogeochemistry.}

The relative concentration (\%) of Felabile in the samples containing sea ice bacterial EPS and the two algal EPS was less than 50\% in all cases after both $24 \mathrm{~h}$ and 9 wk pre-equilibration (Fig. 3B). In the sample containing EPS from the SAZ bloom Felabile was much greater at 63\% after 24 h, and 98\% after 9 wks (Fig. 3B). A comparison of Fe Labile $_{\text {after }} 24 \mathrm{~h}$ and 9 wk pre-equilbration showed an increase in $\mathrm{Fe}_{\text {Labile }}$ over time in the SAZ bloom and E. huxleyi EPS (36\% and 21\% increase, respectively) and a decrease in the P. antarctica and sea ice bacterial EPS (16\% and 45\% decrease, respectively). Conditional stability constants for the sum of all ligands present ( $\log \mathrm{K}_{\mathrm{Fe}}$ sumL $)$ in the $24 \mathrm{~h}$ pre-equilibration samples all followed an inverse pattern of Felabile, where the SAZ bloom had the highest percentage of Felabile (63\%) and the weakest $\log \mathrm{K}_{\mathrm{Fe} \text { 'sumL }}$ (11.17) and P. antarctica had the lowest percentage of Felabile

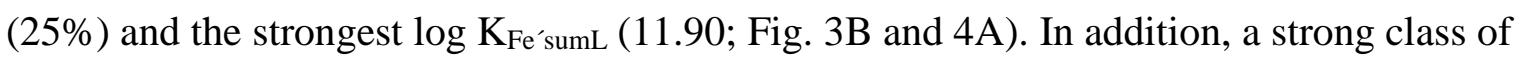
ligand (log $\mathrm{K}_{\mathrm{Fe}} \mathrm{L} \geq 12$ ) was detected in the sea ice bacterial EPS and the EPS isolated from $P$. antarctica, although the concentration of these ligands $\left(\mathrm{L}_{1}\right)$ was less than half that of the sum of all ligands (sumL; Fig. 4A and B). After 9 wk pre-equilibration the $\mathrm{L}_{1}$ signature was not detected in the sea ice bacterial EPS (Fig. 4B). The log $\mathrm{K}_{\mathrm{Fe} \text { 'sumL }}$ calculated in the aged samples were all slightly higher than those calculated after $24 \mathrm{~h}$ pre-equilibration, expect for the SAZ bloom EPS where no ligands were detected, suggesting a degradation of the weaker ligands and a greater influence of the stronger ligands present (Fig. 4B).

Fe-binding HS-like material associated with the sea ice bacteria EPS was relatively low at $<2$ mg SRFA eq g $^{-1}$ EPS (Fig. 3A). HS-like material was present in much higher concentrations in the algal EPS isolates, with the E. huxleyi EPS having almost double the HS-like material compared to the SAZ bloom and P. antarctica EPS (Fig. 3A). Analysis for heme signatures was conducted on all EPS isolates but none were detected (M. Gledhill, pers. comm.).

\subsection{Effect of EPS on Fe solubility.}

The effect of EPS on Fe solubility was determined by the comparison of Fe size distribution, in the colloidal $(0.02$ to $0.2 \mu \mathrm{m})$ and soluble $(<0.02 \mu \mathrm{m})$ fractions in the presence and absence of EPS. The presence of EPS, regardless of origin, significantly increased Fe solubility in both size fractions (Fig.5). The presence of EPS from P. antarctica and the SAZ bloom enhanced soluble Fe to a greater degree than that derived from E.huxleyi, whereas colloidal Fe was enhanced to a greater degree by the E.huxleyi EPS (Fig.5). 
3.6. Effect of EPS and model saccharides on Fe(II) oxidation.

At $22^{\circ} \mathrm{C}$ and $\mathrm{pH} 8.09$ the oxidation rate of $\mathrm{Fe}(\mathrm{II})(30 \mathrm{nM})$ in the unamended $0.2 \mu \mathrm{m}$ filtered Tasman Sea surface seawater (seawater) was extremely rapid, with the Fe(II) half-life being reached within 3 min (Table. 3). When identical samples were measured at $4^{\circ} \mathrm{C}$ the oxidation rate slowed and $\mathrm{Fe}(\mathrm{II})$ half-life was extended by a factor of 10, to $30 \mathrm{~min}$. A similar temperature effect on Fe(II) oxidation was observed in the samples where EPS or model ligands had been added (Table 3). However, of the EPS isolates only the E. huxleyi EPS significantly affected Fe(II) oxidation compared to unamended seawater, accelerating the oxidation rate and reducing the half-life of Fe(II) at both temperatures ( $\mathrm{p}=0.001$; Table 3). At $22^{\circ} \mathrm{C}$ both of the equivalent model saccharides (Fe: $\left.\mathrm{L}=1: 1.66\right)$ also gave significantly faster oxidation rates and shorter Fe(II) half-lives compared to the seawater control (DEX, $\mathrm{p}$ $=<0.005$, GLU, $\mathrm{p}=<0.04$ ), with the dextran comparing very well to the E. huxleyi EPS (Table 3). However, at $4^{\circ} \mathrm{C}$ DEX significantly enhanced oxidation rate and shortened the half-life ( $\mathrm{p}=<0.001)$ whereas GLU did not. In contrast to the rates measured at $22^{\circ} \mathrm{C}$, at $4{ }^{\circ} \mathrm{C}$ the oxidation rate was significantly higher and half-life significantly shorter in the samples containing E. huxleyi EPS compared to the equivalent DEX addition ( $\mathrm{p}=<0.02$, Table 3 ).

Using the model saccharides the ratio of Fe(II) to ligand was varied (Fe:L 1:1.66 to 1:166) to investigate the effect of ligand concentration on $\mathrm{Fe}(\mathrm{II})$ oxidation. At both $22^{\circ} \mathrm{C}$ and $4^{\circ} \mathrm{C}$ the oxidation rate became increasingly faster and the half-life shorter as the concentration of DEX and GLU increased. However the GLU did not show significant response from the seawater control until highest concentration (Fe:L = 1:166; Table 3). Fe to DEX ratios > 1:16.6 were trialled but due to increased viscosity of the samples, variability between replicates was too great to provide reliable results.

\section{Discussion}

4.1. Composition and molar mass distribution of EPS.

Functional analysis revealed that all EPS contained saccharides (i.e. uronic acids and neutral sugars) which have been shown to weakly bind Fe and/or adsorb to Fe oxyhydroxides, thereby preventing aggregation and, as a result, enhancing Fe reactivity and concomitantly bioavailability (Benner, 2011; Croot and Johansson, 2000; Hassler and Schoemann, 2009; Hassler et al., 2011a, b; Sreeram et al., 2004). The sea ice bacterial EPS yielded similar 
relative concentrations of uronic acid and neutral sugars to EPS isolated from a pelagic bacterium (20\% and 51\%, respectively) grown under the same conditions (Hassler et al., 2011a; Mancuso Nichols et al., 2004, 2005). Additionally, in common with the sea ice bacterial EPS of this study, the pelagic bacterial EPS was also found to be of a high molecular mass (HMM; 2.48MDa, number average molar mass). The two cultured algal EPS isolates from $P$. antarctica and $E$. huxleyi had strikingly similar relative concentrations of uronic acid and neutral sugars and all algal EPS were predominantly of low molecular weight (LMW). The average number molar mass of the EPS from the two cultured algal isolates, $P$. antarctica and E. huxleyi, were very similar. The slightly higher average number molar mass of the SAZ bloom EPS may be indicative of the variability of organic material possibly due to the mixed algal community.

The molar mass dispersity $\left(\bigoplus_{\mathrm{M}}\right)$ of $\sim 2$ indicates that all EPS measured here have a heterogeneous molar mass distribution; this was also the case for the pelagic bacteria measured by Hassler et al. (2011a) which had a $\bigoplus_{M}$ of 1.9. Considering the range of components that make up EPS this heterogeneity is indeed expected (Hassler et al., 2011a, b; Mancuso Nichols et al., 2005; Verdugo et al., 2004). The low absorbance Mp observed in both the P. antarctica and E. huxleyi EPS indicates that the majority of UV absorbing compounds were of LMM, whilst the occurrence of two peaks in the SAZ bloom EPS is likely indicative of mixed compounds with a range of UV absorbing components.

The distribution of Fe reflected the difference in molecular size of the algal and bacterial EPS, with the algal EPS Fe being associated with components with smaller hydrodynamic radii $\left(R_{h}\right)$, for the most part $<10 \mathrm{~nm}$. The $R_{h}$ of the three populations found in the sea ice bacterial EPS in this study (peaks at $26 \mathrm{~nm}, 40 \mathrm{~nm}$ and $60 \mathrm{~nm}$ ) again compare very well with those obtained for the pelagic bacterial EPS studied by Hassler et al. (2011a), who used a similar cross flow analytical set up, where $R_{h}$ at peak maximum of $17 \mathrm{~nm}, 40 \mathrm{~nm}$, and $55 \mathrm{~nm}$ were observed. The AFIFFF analyses revealed that the different peaks of the compounds were associated with EPS and each peak could possibly be deconvoluted into several compounds. This suggests that EPS complexes are likely to be over simplified when described in terms of strong $\left(\mathrm{L}_{1}\right)$ and weak $\left(\mathrm{L}_{2}\right)$ Fe-binding ligands.

Direct comparisons between the bacterial and algal EPS are not possible as different growth media were used for the cultures. However, the difference in dominant molecular mass between bacterial (HMM) and algal (LMM) EPS is interesting as it suggests that there are 
compositional differences. These comparisons should, however, be viewed with caution as the molecular cut off used for the bacterial EPS was different to that used for the algal EPS. Furthermore, the preparation by freeze drying of the EPS samples is known alter the conformation of some components of the EPS (i.e. polysaccharides; Hassler et al., 2011a) and so some variability between naturally occurring EPS and the purified EPS used in this study is likely. However, the EPS from the sea ice bacteria used in this study and that from the pelagic bacteria used in the study of Mancuso Nichols et al. (2004, 2005) and Hassler et al. (2011a) show similarities in functional and structural compositions, as do the two cultured algal isolates ( $P$. antarctica and E. huxleyi) with each other. This suggests that these similarities may be common feature rather than an isolated observation, although further studies of bacterial and algal EPS isolates from different strains/species grown under identical conditions would be required in order to reveal any clear overriding similarities.

\subsection{Association of EPS with macronutrients and trace elements}

EPS is known to contain strong metal-binding groups and has the ability to form complexes with a wide variety of metals (Fe, Zn, Cu, Cd, Co, Mn, Mg, Ag, Ni, Pb) (Decho, 1990; Douchet et al., 2007). The association of EPS with nutrients in this study, and also in bacterial EPSs studied by Hassler et al. (2011b) and Gutierrez et al. (2012), may indicate that EPS not only have the ability to bind Fe, but also a suite of other constituents that are essential to phytoplankton growth. Hassler et al. (this issue) calculated a substantial enhancement of $\mathrm{Zn}, \mathrm{Co}$, and $\mathrm{Cu}$, in field incubations that had been enriched with pelagic Southern Ocean bacterial EPS (Mancuso Nichols et al., 2004, 2005; Hassler et al., 2011a, b). The study (Hassler et al., this issue) also observed an increase in $\mathrm{NO}_{\mathrm{x}}$ concentration in bacterial EPS enriched incubations which was approximately 15-fold greater than that measured in situ in the low nutrient/low chlorophyll Tasman Sea (Hassler et al., 2014). The observations of Hassler et al. (this issue) suggest that EPS may be efficient at sequestering/scavenging macronutrients, as well trace metals, from the water column. However, macronutrients are mainly anionic and are therefore unlikely to bind to EPS via the same mechanism as cationic trace elements, due to the net negative charge of EPS at the $\mathrm{pH}$ of seawater (McCarthy et al., 1996).

Inputs of atmospheric dust are known to periodically be deposited into the SAZ region (Bowie et al., 2009; Mongin et al., 2011; Cropp et al., 2012). The relatively high concentrations of $\mathrm{Al}, \mathrm{Mn}, \mathrm{Pb}$ and $\mathrm{Cd}$ measured in the SAZ bloom EPS, compared to those 
measured in the cultured algal EPS may, therefore, be the result of contamination from particulate matter from the surrounding waters in the SAZ (i.e. from colloidal clay particles), although dFe profiles (Hassler et al., 2014) did not provide evidence of enrichment of trace elements into surface waters of the sampling region. For the laboratory cultures; the growth media used for algal culture contained comparatively high concentrations of nutrients in order to attain sufficient biomass. Additionally, Fe would have been introduced to the sea ice bacteria growth media via the yeast and peptone, although AFIFFF measurements of growth media alone indicate that $\geq 90 \%$ of this was removed during the EPS isolation process. The use of glass fiber filters can also represent a background contamination of trace elements, including Fe. Although the filters used during the initial EPS isolation step from the algal cultures were acid-rinsed to minimise this effect, leaching of metals from the filters might have occurred. Scavenging of trace elements onto the EPS due to contamination might, therefore, have taken place. For this study, direct comparison as to the acquisition efficiency of each EPS was not possible as the procedure to exclude cells differed, the concentration of trace elements and macronutrients in solution varied between media and would be greatly enriched compared to in situ concentrations. However, these experimental artefacts do not prevent our findings of the effect of EPS on iron biogeochemistry.

\subsection{Effect of EPS on Fe biogeochemistry.}

The conditional stability constants in respect of inorganic Fe-binding $\left(\mathrm{K}_{\mathrm{Fe}^{\prime} \mathrm{L}}\right)$ of all EPS in this study compare well to previous measurements of algal exudates $\left(10^{11.5}\right.$, Boye and van den Berg, 2000; $10^{12}$, Rijkenberg et al., 2008), and also fall within the range of previous open ocean measurements ( $\mathrm{K}_{\mathrm{FeL}}=10^{11}$ to $10^{13.5}$, Boye et al., 2001, 2005; Cullen et al., 2006; Frew et al., 2006; Ibisanmi et al, 2011; Kondo et al., 2008; Rue and Bruland, 1995, 1997). This suggests that both bacterial and algal EPS are significant contributors to the marine organic ligand pool, particularly in the $\mathrm{L}_{2}$ ligand class. A smaller concentration of ligands that would comparable to what is operationally defined as $\mathrm{L}_{1}$ class $\left(\mathrm{K}_{\mathrm{Fe}}{ }^{\prime} \mathrm{L} \geq 10^{12}\right.$, Gledhill and Buck, 2012, and refs therein; Rue and Bruland, 1995, 1997) was also measured in the sea ice bacterial EPS and P. antarctica EPS after $24 \mathrm{~h}$ pre-equilibration. Here, the $\mathrm{K}_{\mathrm{Fe}} \mathrm{L}$ are similar to those measured for bacterially produced siderophores (Vraspir and Butler, 2008 and refs therein), which are considered to be a key players in Fe complexation. However, the limited effect that EPS had on Fe(II) oxidations kinetics suggests that very strong Fe(III) binding ligands were not dominating. 
Although the $\mathrm{K}_{\mathrm{Fe} \text { 'sumL }}$ were slightly higher in the aged (9 wk pre-equilibration) samples compared to those measured after $24 \mathrm{~h}$ in all cases except for the SAZ bloom, the $\mathrm{L}_{1}$ ligand signature measured in the sea ice bacterial EPS after $24 \mathrm{~h}$ was not detected. The material associated with $P$. antarctica maintained a conditional stability constant representative of an $\mathrm{L}_{1}$ ligand after 9 wk pre-equilibration but ligand concentration was diminished. Despite the apparent resilience in terms of Fe-binding capacity, these findings indicate that Fe-binding EPS are degraded over time and likely to be highly reactive in surface waters.

Concomitant with the decline in ligand concentration over time one might expect an increase

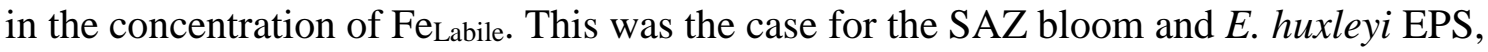
however Fe $e_{\text {Labile }}$ decreased in the P. antarctica and sea ice bacterial EPS. It is possible that changes in Fe-EPS association with time could have resulted in conformational changes in the aged samples as previously suggested by Hassler et al. (2011a). Formation of Fe oxide and/or adsorption of Fe onto vessel walls are processes known to occur during long equilibration periods, especially in non-acidic solutions. However, the presence of excess organic ligands is known to maintain iron in solution (Boyd and Ellwood, 2010). Here, to verify that inorganic Fe adsorption processes were not dominating, we compared the decrease in $\mathrm{dFe}, \mathrm{Fe}_{\text {labile }}$ and analytical sensitivity of the CLE-AdCSV in presence of $2.5 \mathrm{nM}$ inorganic Fe and 2.5nM Fe-EPS solutions following 24h and 9 weeks equilibration. Following the 9 week equilibration, dFe concentrations decreased between 7 and $17 \%$ in presence of EPS, suggesting that EPS was preventing a major loss of dFe. Moreover, the decrease in Felabile and analytical sensitivity were significantly greater in presence of inorganic iron (3.5-fold and 3.1-fold, respectively; Hassler et al., 2011a) than in the presence of Fe-EPS (1.2 to 1.8-fold, this study). These observations suggest that organic ligands present in EPS retard Fe oxide formation and/or adsorption onto containers, suggesting that these factors were not dominant in the change of $\mathrm{Fe}_{\text {Labile }}$ and organic ligands measured in this study.

Although siderophores are identified as important Fe-binding ligands and are known to have conditional stability constants in the $\mathrm{L}_{1}$ class there are few studies that quantify the concentration of siderophores in the oceans (Gledhill and Buck, 2012; Mawji et al., 2008; Velasquez et al., 2011). Studies by Mawji et al. (2008) and Velasquez et al. (2011) identified and measured hydroxamate siderophores in the Atlantic Ocean (Mawji et al., 2008) and in coastal and Sub-Antarctic waters near the Otago Peninsula, New Zealand (Velasquez et al., 2011) at concentrations of 3 to 20 pM and 5 to 11 pM, respectively. Velasquez et al. (2011) estimated that the contribution of hydroxamate siderphores to the ligand pool was very small, 
accounting for $<1 \%$ of the total $\mathrm{L}_{1}$ ligands measured. Whilst it is noted that there are potentially other Fe-binding siderophores present in seawater that current analytical methods do not detect (Amin et al., 2009; Gledhill and Buck, 2012, Vraspir and Butler, 2011) the calculated concentration of Fe-binding ligands associated with the SAZ natural bloom EPS (table 4) are an order of magnitude higher than is currently reported for siderophores.

Using the concentration of EPS purified in the SAZ (0.17 $\mathrm{mg} \mathrm{L}^{-1}$, Table 4), one can calculate a contribution of $0.64 \mu \mathrm{M}$ carbon from saccharides (Table 1) which corresponds to $1 \%$ of the marine dissolved organic carbon (Hansell and Carlson, 2002). Using this contribution as a relevant EPS concentration in seawater, the concentrations of dFe, organic ligands and HSlike material associated with each EPS were then calculated and compared with measured data in the SAZ (Table 4). The concentrations of dFe associated with the purified EPS (0.04 to $0.61 \mathrm{nM}$ ) were comparable to those reported in the SAZ (Table 4). The calculations indicate that EPS (both bacterial and algal) could account for the up to $100 \%$ of organic ligands measured in the SAZ (in situ). Furthermore, the contribution of HS-like material from the SAZ bloom EPS could represent a substantial proportion of the total HS-like material measured in situ in the euphotic zone, in this case $~ 14 \%$.

The ability of organic ligands to outcompete others for Fe-binding is determined by both their concentration and conditional stability constant (Morel and Hering, 1993). The comparatively high concentration of EPS that is likely to be present in surface waters suggests that EPS, regardless of origin, may be particularly effective in competing for Fe in the presence of other Fe-binding organic ligands, including siderophores.

The mechanism by which both bacterial and algal EPS bind Fe is still unresolved. The conditional stability constants measured here are greater than those that have been measured for known functional components of EPS, i.e. uronic acid, and as such may bind a portion of the Fe(III) present. Polysaccharides are a significant constituent of EPS that have been reported throughout Southern Ocean waters (e.g. Panagiotopoulos and Sempéré 2005) and whose vertical distribution was found to correlate with the distribution of colloidal Fe (Benner, 2011). In the Southern Ocean, it is suggested that much of the dissolved $(<0.4 \mu \mathrm{m})$ ligands are actually present in the colloidal fraction (0.02 - $0.4 \mu \mathrm{m}$; Boye et al. 2010). Because siderophores are small organic compounds ( $<1$ kDa, Neilands, 1981a,b, ) that are able to solubilize Fe oxyhydroxides (Vala et al., 2006; Velasquez et al., 2011), they might be expected to be found in the soluble phase. However, soluble ligands show a lower affinity for 
Fe-binding than colloidal ligands (Boye et al., 2010), whereas siderophores generally have a high affinity for Fe-binding. Due to their structure (amphiphilic with an Fe(III)-binding head group separate from a long fatty-acid tail), many marine siderophores may attach to, or form, particles in the colloidal size fraction. This may be via the formation micelles or multi-layer vesicles by free siderophores, through attachment to cell walls or association with organic colloidal material (Buck et al. (2007; Butler and Theisen , 2010). EPS are mostly colloidal organic macromolecules which could form a gel phase (e.g. Verdugo et al., 2004) and trap other important organic ligands such as hemes or siderophores (Gledhill and Buck, 2012) in the colloidal fraction. In addition, the EPS may adsorb to very small Fe oxyhydroxide particles, resulting in prevention of aggregation of these particles thereby increasing $\mathrm{Fe}$ bioavailability. It is noteworthy that heme signatures were not detected in any of the EPS isolates from this study; however specific siderephore signatures (e.g., Velasquez et al., 2011) were not analyzed here.

Organic ligands can improve and maintain Fe solubility in marine waters (Boyd and Ellwood, 2010; Johnson et al., 1997), although in general the organic ligands responsible for this behaviour are not identified. In our experimental set up, Fe-binding organic ligands detected by the CLE-AdCSV varied between EPS; 6.5, 4.9, 7.6 and $13.3 \mathrm{nM}$ for the EPS from sea-ice bacteria, P. Antarctica, E. Huxleyi, and SAZ bloom, respectively. Here there was thus no simple correlation between the effect of Fe solubility and Fe-binding organic ligand concentrations. It is to be noted that the detection of Fe-binding organic ligands is somewhat defined by the analytical window of the CLE-AdCSV technique used (Bruland et al., 2000). Mass balance studies in size fractionation of trace elements (Buffle et al., 1992, Gustaffson et al., 1996; Wen et al., 1996) have indicated that substantial adsorptive losses of colloidal material during ultrafiltration could occur ( 35 \% for Fe; Wen et al 1996), potentially resulting in an underestimation in the relative concentration (\%) of colloidal Fe in this study.

However, this study demonstrated that the presence of both bacterial and algal EPS improved the Fe solubility/filterability of both soluble and colloidal Fe. Furthermore, Fe solubility (or, at least, filterability as we recognise that the EPS may have acted to prevent aggregation of Fe oxyhydroxides) in the presence of algal EPS was greater in the colloidal fraction than that observed in the soluble fraction. This has important implications for Fe cycling in natural waters. Past studies have shown that colloidal Fe is often much more abundant in surface waters than soluble Fe and despite the fact the soluble Fe is generally considered to be more biologically available to phytoplankton (Boye et al., 2010; Wu et al., 2001), there is some 
evidence that Fe bound to reactive (i.e. susceptible to organic or photo-chemical reduction) LMM newly formed colloids may be bioavailable to some phytoplankton (Chen and Wang, 2001; Chen et al., 2003). In addition, the aggregation and settling behaviour together with scavenging of colloidal Fe may, in fact, enhance Fe removal from surface waters (Boye et al., 2010; Wu et al., 2001).

Shipboard measurements of Fe(II) concentration have indicated slower than expected oxidation in some oceanic regions (Croot and Laan, 2002; Hansard et al., 2009; Roy et al., 2008). This has been attributed to low temperature, the presence of low concentrations of the oxidant $\mathrm{H}_{2} \mathrm{O}_{2}$ and/or the presence of $\mathrm{Fe}(\mathrm{II})$ binding organic ligands, although evidence of specific Fe(II) binding ligands in seawater is still debated (Croot and Laan, 2002; Miller et al., 2012; Roy et al, 2008). In this study the half-life of $\mathrm{Fe}(\mathrm{II})$ at $22^{\circ} \mathrm{C}$ in the unamended seawater was reached within the 2 to 3 min predicted for seawater at $\mathrm{pH} 8.0\left(15\right.$ and $25^{\circ} \mathrm{C}$; Millero et al. 1987). Although temperature slowed Fe(II) oxidation, the addition of EPS, GLU or DEX did not. This may be evidence that none of the EPS isolates or model ligands were binding $\mathrm{Fe}(\mathrm{II})$ to any measureable degree, or possibly that the complexes formed underwent rapid oxidation. It is often expected that the presence of organic ligands slows $\mathrm{Fe}(\mathrm{II})$ oxidation, but observations such as those in this study are not unusual and variable effects on Fe(II) oxidation in the presence of different organic materials have been reported. For example, under laboratory conditions, in $\mathrm{NaCl}$ solutions or seawater, the synthetic ligand ethylene glycol tetraacetic acid (EGTA) was observed to completely inhibit oxidation, salicylic acid decreased oxidation, but phthalic acid and ethylenediaminetetraacetic acid (EDTA, synthetic ligand) enhanced Fe(II) oxidation. Alanine and glutamic acid had a negligible effect (Santana-Casiano et al., 2000, 2004). Additionally, the same compound may behave differently depending on the experimental or environmental conditions to which it is exposed. For example, at pH 6.0 citrate has been shown to enhance Fe(II) oxidation, but at a higher pH (i.e. pH 8.0) Fe(II) oxidation decreased (Pham and Waite, 2008).

In natural seawater from the Sub-Arctic Pacific, Roy et al. (2008) and Roy and Wells (2011) demonstrated both a slowing and acceleration of Fe(II) oxidation. Both responses were attributed to the presence of organic ligands. However, in the 2011 study the authors noted a clear relationship between enhanced Fe(II) oxidation and phytoplankton biomass and concluded that the presence of biologically produced strong Fe(III) binding ligands, specifically bacterially produced siderophores, may have been responsible for the accelerated 
Fe(II) oxidation rates. Similarly, Millero et al. (1987) observed that the half-life of Fe(II) in outflowing Biscayne Bay waters was two to five times greater than those found in Gulf Stream waters. This behaviour was attributed to variable concentrations of organic ligands in the Bay waters and the presence LMM ligands. Enhanced Fe(II) oxidation was certainly apparent in the presence of E.huxleyi EPS at both $22^{\circ} \mathrm{C}$ and $4^{\circ} \mathrm{C}$, but no significant effect was observed in the presence of the SAZ bloom EPS at the excess ligand concentration used. Due to a limited amount of isolate in both cases, increased EPS concentrations could not be tested and so it is not possible to ascertain whether a larger excess of EPS would have resulted in a similar enhancement of Fe(II) oxidation. However, enhanced Fe(II) oxidation might be expected in the presence of a relatively strong Fe(III)-binding organic ligand or Fe(II) oxidant (i.e. $\mathrm{H}_{2} \mathrm{O}_{2}$ and superoxide). The P. antarctica EPS contained a component that was measured as an $\mathrm{L}_{1}$ ligand which may promote the acceleration of Fe(II) oxidation. Analysis for the presence of significant Fe(II) oxidising products was not conducted, nor was sufficient $P$. antarctica EPS available to enable further investigation of oxidation rate kinetics. Thus, the idea that the $\mathrm{L}_{1}$ ligand components of EPS may, like siderophores, make up part of the biological pool of ligands responsible for Fe(II) removal cannot be confirmed without further experiments.

\subsection{Conclusions.}

Until now EPS have been an under-studied group of Fe-binding organic ligands. This study has highlighted many, previously unknown, functional and molar mass properties of bacterial and algal EPS, as well as demonstrating the significant effect that EPS may have on Fe biogeochemistry. Much of the previous research investigating bioavailability and Fe complexation with organic ligands has focused on bacterially produced siderophores. This study shows that Fe bound to EPS enhances Fe solubility (and/or perhaps prevents Fe oxyhydroxide aggregation) and is likely to have the capacity to compete for Fe with siderophores, primarily due to relatively high concentrations at which Fe-binding ligands associated with EPS occur, but may also enhance the removal of Fe(II) from surface waters. However, Fe associated with EPS has been shown to be bioavailable and efficient in promoting phytoplankton growth and impact on community structure (Hassler et al., this issue).

Whilst siderophores are an extremely important part of the organic ligand pool this study demonstrates that the role of EPS in Fe biogeochemistry is also significant. The heterogeneity 
of the structure of EPS, as well as the wide variety of components from which it is composed, make EPS a challenging organic ligand to resolve and thus the mechanism by which EPS binds Fe is far from resolved. To further our understanding of the dynamics of Fe-limited oceans, and also improve existing biogeochemical models so that oceanic carbon fixation can be accurately predicted, the role of both bacterial and algal EPS in Fe biogeochemical cycling deserves further consideration.

\section{Acknowledgments}

The authors thank the Australian Research Council (Discovery Project DP1092892 and LIEF grant LE0989539), UTS Chancellor Fellowship and Climate Change Cluster C3 group, and the Swiss National Science Foundation (PP00P2_138955) schemes for funding. Authors also wish to thank Dr Martha Gledhill for the heme analysis, Dr Martina Doblin, the guest editor, and two anonymous reviewers whose comments improved the final version of this manuscript, and Prof Peter Ralph for his support of this project. Thanks also to the officers and crew of the RV Southern Surveyor (PINTS and GEOTRACES GP13 voyages) and the Marine National Facility support team. 


\section{References}

Aluwihare, L.I., Repeta, D.J., 1999. A comparison of the chemical characteristics of oceanic DOM and extracellular DOM produced by marine algae. Mar. Ecol. Prog. Ser. 186, 105-17.

Amin, S.A. Green, D.H., Hart, M.C., Küpper, F.C., Sunda, W.G., Carrano, C.J., 2009. Photolysis of iron-siderophore chelates promotes bacterial-algal mutualism. PNAS. 106, 1707117076.

Barbeau, K., Rue, E.L., Bruland, K.W., Butler, A., 2001. Photochemical cycling of iron in the surface ocean mediated by microbial iron(III)-binding ligands. Nature. 413, 409-413.

Barbeau, K., Rue, E.L., Trick, C.G., Bruland, K.W., Butler, A., 2003. Photochemical reactivity of siderophores produced by marine heterotrophic bacteria and cyanobacteria based on characteristic Fe(III) binding groups. Limnol. Oceanogr. 48, 1069-1078.

Benner, R., 2011. Loose ligands and available iron in the ocean. PNAS. 108, 893-894.

Bowie, A.R., Townsend, A.T., Lannuzel, D., Remenyi, T.A., van der Merwe, P., 2010. Modern sampling and analytical methods for the determination of trace elements in marine particulate material using magnetic sector inductively coupled plasma-mass spectrometry. Anal. Chim. Acta. 676, 15-27.

Bowie, A.R., Griffiths, F.B., Dehairs, F., Trull, T.W., 2011. Oceanography of the subantarctic and Polar Frontal Zones south of Australia during summer: Setting for the SAZ-Sense study. Deep-Sea Res. II. 58, 2059-2070.

Boyd, P.W., Ellwood, M.J., 2010. The biogeochemical cycle of iron in the ocean. Nature Geosci. 3, 675-682.

Boye, M., van den Berg, C.M.G., 2000. Iron availability and the release of iron-complexing ligands by Emiliania huxleyi. Mar. Chem. 70, 277-287.

Boye, M., van den Berg, C.M.G., de Jong, J.T.M., Leach, H., Croot, P., de Baar, H.J.W., 2001. Organic complexation of iron in the Southern Ocean. Deep-Sea Res. I. 48, 1477-1497. 
Boye, M., Nishioka, J., Croot, P.L., Laan, P., Timmermans, K.R., de Baar, H.J.W., 2005. Major deviations of iron complexation during 22 days of a mesoscale iron enrichment in the open Southern Ocean. Mar. Chem. 96, 257-271.

Boye, M., Nishioka, J., Croot, P., Laan, P., Timmermans, K.R., Strass, V.H., Takeda, S., de Baar, H.J.W., 2010. Significant portion of dissolved organic Fe complexes in fact is Fe colloids. Mar. Chem. 122, 20-27.

Bruland, K.W., Rue, E.L., Donet, J.R., Skrabal, S.A., Moffett, J.W., 2000. Intercomparison of voltammetric techniques to determine the chemical speciation of dissolved copper in a coastal seawater sample. Anal. Chen. Acta. 405, 99-113.

Buck, K.N., Lohan, M.C., Berger, C.J.M., Bruland, K.W., 2007. Dissolved iron speciation intwo distinct river plumes and an estuary: Implications for riverine iron supply. Limnol. Oceanogr. 52, 843-855.

Buffle, J., Perret, D., Newman, M., 1992. The use of filtration and ultrafiltration for size fractionation of aquatic particles, colloids, and macromolecules. In: Buffle, J., van Leeuwen, H.P. Eds.., Environmental Particles, Vol. 1. Lewis Publishers, Boca Raton, pp. 171-230.

Butler, A., Theisen, R.M., 2010. Iron(III)-siderophore coordination chemistry: Reactivity of marine siderophores. Coordin. Chem. Rev. 254, 288-296.

Chen, M., Wang, W-X., 2001. Bioavailability of natural colloid-bound iron to marine plankton: Influences of colloidal size and aging. Limnol. Oceanogr. 46, 1956-1967.

Chen, M., Dei., R.C.H., Wang, W-X., Guo, L.D., 2003. Marine diatom uptake of iron bound with natural colloids of different origins. Mar. Chem. 81, 177-189.

Chen, M., Wang, W-X., Guo, L., 2004. Phase partitioning and solubility of iron in natural seawater controlled by dissolved organic matter. Glob. Biogeochem. Cycles. 18, GB 4013, doi:10.1029/2003GB00216o.

Croot, P.L., Johansson, M., 2000. Determination of iron speciation by cathodic stripping voltammetry in seawater using the competing ligand 2-(-Thiazolylazo)-p-crestol (TAC). Electroanalysis. 12, 565-576. 
Croot, P.L., Bowie, A.R., Frew, R.D., Maldonado, M.T., Hall, J.A., Safi, K.A., La Roche, J., Boyd, P.W., Law, C.S., 2001. Retention of dissolved iron and Fe(II) in an iron induced Southern Ocean phytoplankton bloom. Geophys. Res. Let. 28, 3425-3428.

Croot, P.L., Laan, P., 2002. Continuous shipboard determination of Fe(II) in polar waters using flow injection analysis with chemiluminescence detection. Anal. Chim.Acta. 466, 261273.

Cullen, J.T., Bergquist, B.A., Moffett, J.W., 2006. Thermodynamic characterization of the partitioning of iron between soluble and colloidal species in the Atlantic Ocean. Mar. Chem. 98, 295-303.

de Baar, H.J.W., de Jong, J.T.M., 2001. Distributions, sources and sinks of iron in seawater. In: The biogeochemistry of iron in seawater. Eds. D.R. Turner, K.A. Hunter. John Wiley \& Sons, UK. pp. 123-254.

Decho, A.W., 1990. Microbial exopolymer secretions in ocean environments: Their role(s) in food webs and marine processes. In: Oceanography and Marine Biology Annual Review. Ed. M. Barnes. Aberdeen Univ Press, Aberdeen, Scotland. pp 73-153.

DiTullio, G.R., Grebmeier, J.M., Arrigo, K.R., Lizotte, M.P., Robinson, D.H., Leventer, A., Barry, J.P., Van Woert, M.L., Dunbar, R.B., 2000. Rapid and early export of Phaeocystis antarctica blooms in the Ross Sea, Antarctica. Nature. 404, 595-598.

Douchet., F.J., Lead, J.R., Santschi., P.H., 2007. Colloid - Trace element interactionsin aquaticsystems. In Environmental Colloids and Particles: Behaviour, Separation and Characterisation. Eds: K.J. Wilkinson, J. R. Lead. Wiley. pp 95-157.

Frew, R.D., Hutchins, D.A., Nodder, S., Sanudo-Wilhelmy, S., Tovar-Sanchez, A., Leblanc, K., Hare, C.A., Boyd. P.W., 2006. Particulate iron dynamics during FeCycle in subantarctic waters southeast of New Zealand. Glob. Biogeochem. Cycles. 20, GB1S93, doi: 10.1029/2005GB002558.

Gerringa, L.J.A., Herman, P.M.J., Poortvliet, T.C.W., 1995. Comparison of the linear van den Berg/Ružić transformation and a non-linear fit of the Langmuir isotherm applied to $\mathrm{Cu}$ speciation data in the estuarine environment. Mar. Chem. 48, 131-142. 
Gledhill, M., van den Berg, C.M.G., 1994. Determination of the complexation of iron(III) with natural organic complexing ligands in seawater using cathodic stripping voltammetry. Mar. Chem. 47, 41-54.

Gledhill, M., McCormack, P., Ussher, S., Achterberg, E.R., Fauzi, R., Mantoura, C., Worsford, P.J., 2004. Production of siderophore type chelates by mixed bacterioplankton populations in nutrient enriched seawater incubations. Mar. Chem, 88, 75 - 83.

Gledhill M., Buck, K.N., 2012. The organic complexation of iron in the marine environment: a review. Front Microbiol. 3, 69. doi: 10.3389/fmicb.2012.00069.

Gledhill, M., 2014. The detection of iron protoporphyrin (heme b) in phytoplankton and marine particulate material by electrospray ionisation mass spectrometry - comparison with diode array detection. Anal. Chim. Acta. 841, 33-43. doi: 10.1016/j.aca.2014.06.045.

Grasshoff, K.M., Ehrhardt, M., Kremling, K., 1983. Methods of Seawater Analysis. Verlag Chemie, Weinheim, Germany.

Gustafsson, O., Buesseler, K., Gschwend, P., 1996. On the integrity of cross-flow filtration for marine organic colloids. Mar. Chem. 55, 93-112.

Gutierrez, T., Biller, D.V., Shimmield, T., Green, D.H., 2012. Metal binding properties of the EPS produced by Halomonas sp. TG39 and its potential in enhancing trace element bioavailability to eukaryotic phytoplankton. Biometals. 25, 1185-1194.

Hales, B., van Greer, A., Takahashi, T., 2004. High-frequency measurements of seawater chemistry: Flow-injection analysis of macronutrients, Limnol. Oceanogr. Methods. 2, 91101, doi:10.4319/lom.2004.2.91.

Hansard, S.P., Landing, W.M., Measures, C.I., Voelker, B.M., 2009. Dissolved iron(II) in the Pacific Ocean: Measurements from the PO2 and P16N CLIVAR/CO $\mathrm{CO}_{2}$ repeat hydrography expeditions. Deep-Sea Res. I. 56, 1117-1129.

Hansell, D.A., Carlson, C.A., 2002. Biogeochemistry of marine dissolved organic matter Academic Press, San Diego. 
Harris, D.C., 1998. Nonlinear least-squares curve fitting with Microsoft Excel Solver. $J$. Chem. Educ. 75: 119 - 121.

Hassler, C.S., Schoemann, V., 2009. Bioavailability of organically bound iron in controlling Fe to model phytoplankton of the Southern Ocean. Biogeosciences. 6, 2281-2296.

Hassler, C.S., Alasonati, E., Mancuso Nichols, C.A., Slaveykova, V.I., 2011a. Exopolysaccharides produced by bacteria isolated from the pelagic Southern Ocean - Role in Fe binding, chemical reactivity, and bioavailability. Mar. Chem. 123, 88-98.

Hassler, C.S., Schoemann, V., Mancuso Nichols, C., Butler, E.C.V., Boyd, P.W., 2011b. Saccharides enhance iron bioavailability to Southern Ocean phytoplankton. PNAS. 108, 1076-1081.

Hassler, C.S., Legiret, F-E., Butler, E.C.V., 2013. Measurement of iron speciation in seawater at $4{ }^{\circ} \mathrm{C}$ : The use of competitive ligand exchange-adsorptive cathodic stripping voltammetry. Mar. Chem. 149, 63 - 73.

Hassler, C.S., Ridgway, K.R., Bowie, A.R., Butler, E. C. V., Clementson, L.A., Doblin, M.A., Davies, D.M., Law, C., Ralph, P.J., van der Merwe, P., Watson, R., Ellwood, M.J., 2014. Primary productivity induced by iron and nitrogen in the Tasman Sea: an overview of the PINTS expedition. Mar. Freshwater Res. 65, 517-537. doi. Org/10.1071/MF13137.

Hassler, C.S., Norman, L., Angles, E., Mancuso Nichols, C.A., Clementson, L.A., Robinson, C., Watson, R.J., Doblin, M.A., 2014. Exopolymeric substances can relieve iron limitation in oceanic phytoplankton. Mar. Chem. This issue

Hoagland, K.D., Rosowski, J.R., Gretz, M.R., Roemer, S.C., 1993. Diatom extracellular polymeric substances: function, fine structure, chemistry, and physiology. J. Phycol. 29, 537566.

Hudson, R.J.M., Covault, D.T., Morel, F.M.M., 1992. Investigations of iron coordination and redox chemistry reactions in seawater using ${ }^{59} \mathrm{Fe}$ radiometry and ion-pair solvent extraction of amphiphilic iron complexes. Mar. Chem. 38, 209-235

Hunter, K.A., Boyd, P.W., 2007. Iron-binding ligands and their role in the ocean 
biogeochemistry of iron. Environ. Chem. 4, 221-232. doi:10.1071/EN01012.

Hutchins, D.A., Witter, A., Butler, A., Luther III, G.W., 1999. Competition among marine phytoplankton for different chelated iron species. Nature. 400, 858-861.

Ibisanmi, E., Sander, S.G., Boyd, P.W., Bowie, A.R., Hunter, K.A., 2011. Vertical distributions of iron-(III) complexing ligands in the Southern Ocean. Deep-Sea Res. II. 58, 2113-2125.

Johnson, K.S., Gordon, R.M., Coale, K.H., 1997. What controls dissolved iron concentration in the world ocean? Mar. Chem. 57, 137-161.

Kondo, Y., Takeda, S., Nishioka, J., Obata, H., Furuya, K., Johnson, W.K., Wong, C.S., 2008. Organic iron (III) complexing ligands during an iron enrichment experiment in the western subarctic North Pacific. Geophys. Res. Lett. 35, L12601, doi: 10.1029/2008GL033354.

Kuma, K., Nishioka, J., Matsunaga, K., 1996. Controls on iron(III) hydroxide solubility in seawater: The influence of pH and natural organic chelators. Limnol. Oceanogr. 41, 396-407.

Kuma, K., Katsumoto, A., Kawakami, H., Takatori, F., Matsunaga, K., 1998. Spatial variability of Fe(III) hydroxide solubility in the water column of the northern North Pacific Ocean. Deep-Sea. Res. I. 45, 91-113.

Laglera, L.M., Battaglia, G.,van den Berg, C.M.G., 2007. Determination of humic substances in natural waters by cathodic stripping voltammetry of their complexes with iron. Anal. Chim. Acta. 599, 58-66.

Lin, J., Kester, D.R., 1992. The kinetics of Fe(II) complexation by ferrozine in seawater. Mar. Chem. 38, 283-301.

Liu, X., Millero, F.J., 2002. The solubility of iron in seawater. Mar. Chem. 77, 43-54.

Maldonado, M.T., Price, N.M., 1999. Utilization of iron bound to strong organic ligands by plankton communities in the subarctic Pacific Ocean. Deep-Sea. Res. 46, 2447-2473.

Maldonado, M.T., Strzepek, R.F., Sander, S., Boyd, P.W., 2005. Acquisition of Fe bound to 
strong organic complexes, with different Fe binding groups and photochemical reactivities, by plankton communities in Fe-limited subantarctic waters. Glob. Biogeochem. Cycles. 19, GB4S23. doi:10.1029/2005GB002481.

Mancuso Nichols, C.A., Garon, S., Bowman, J.P., Raguénès, G., Guézennec, J., 2004.

Production of exopolysaccharides by Antarctic marine bacterial isolates. J. Applied. Microbiol. 96, 1057-1066, doi:10.1111/j.1365-2672.2004.02216.x

Mancuso Nichols, C., Lardière, S.G., Bowman, J.P., Nichols, P.D., Gibson, J., Guézennec, J., 2005. Chemical characterization of exopolysaccharides from Antarctic marine bacteria. Microb. Ecol. 49, 578-589.

Mawji, E., Gledhill, M., Milton, J.A., Tarran, G.A., Ussher, S., Thompson, A., Wolff, G.A., Worsford, P.J., Achterberg, E.P., 2008. Hydroxamate siderophores: Occurrence and importance in the Atlantic Ocean. Environ. Sci. Technol. 42, 8675-8680.

Mawji, E., Gledhill, M., Milton, J.A., Zubkov, M.V., Thompson, A., Wolff, G.A., Achterberg, E.P., 2011. Production of siderophore type chelates in Atlantic Ocean waters enriched with different carbon and nitrogen sources. Mar. Chem. 124, 90-99.

McCarthy, M., Hedges, J., Benner, R.., 1996. Major biochemical composition of dissolved high molecular weight organic matter in seawater. Mar. Chem. 55, 281-297.

Miller, C.J., Lee, S.M.V., Rose, A.L., Waite, T.D., 2012. Impact of natural organic matter on $\mathrm{H}_{2} \mathrm{O}_{2}$-mediated oxidation of Fe(II) in seawater. Environ. Sci. Technol. 46, 11078-11085.

Millero, F.J., Sotolongo, S., Izaguirre. M., 1987. The oxidation kinetics of Fe(II) in seawater. Geochim. Cosmochim. Acta. 51, 793-801.

Morel, F.M.M., Hering, J.G., 1993. Principles and Applications of Aquatic Chemistry, Wiley, New York.

Murray, J. W., Gill, G., 1978. The geochemistry of iron in Puget Sound. Geochim. Cosmochim. Acta. 42, 9-19.

Myklestad, S.M., Skånøy, E., Hestmann, S., 1997. A sensitive and rapid method for analysis of mono- and polysaccharides in seawater. Mar. Chem. 56, 279-286. 
Nanninga, H. J., Ringenaldus, P. \& Westbroek, P., 1996. Immunological quantification of a polysaccharide formed by Emiliania huxleyi. J. Mar. Syst. 9, 67-74.

Neilands, J.B., 1981a. Iron-absorption and transport in microorganisms. Annu. Rev. Nutr. 1, 27-46.

Neilands, J.B., 1981b. Microbial iron compounds. Annu. Rev. Biochem. 50, 715-731.

Panagiotopoulos, C., Sempéré, R., 2005. Analytical methods for the determination of sugars in marine samples: A historical perspective and future directions. Limnol. Oceanogr. Methods 3, 419- 454.

Pham, A.N., Waite, T.D., 2008. Modelling the kinetics of Fe(II) oxidation in the presence of citrate and salicylate in aqueous solutions at pH 6.2-8.0 and $25{ }^{\circ} \mathrm{C}$. J. Phys. Chem. 112, 53955405.

Price, N.M., Harrison, G.I., Hering, J.G., Hudson, R.J., Nirel, P.M.V., Palenik, B., Morel, F.M., 1989. Preparation and chemistry of the artificial algal culture medium AQUIL. Biol. Oceanogr. 6, 443-361.

Pullin, J.M., Cabaniss, S.E., 2003. The effects of pH, ionic strength, and iron-fulvic acid interactions on the kinetics of non-photochemical iron transformations. II. The kinetics of thermal reduction. Geochim. Cosmochim. Ac. 67, 4079-4089.

Reszat, T.N, Hendry, M.J., 2005. Characterizing dissolved organic carbon using asymmetrical flow field-flow fractionation with on-line UV and DOC detection. Anal. Chem. 77, 4194-4200.

Rijkenberg, M.J.A., Gerringa, L.J.A., Carolus, V.E., Velzeboer, I., de Baar, H.J.W., 2006. Enhancement and inhibition of iron photoreduction by individual ligands in open ocean seawater. Geochim. Cosmochim. Acta. 70, 2790-2805.

Rijkenberg, M.J.A., Gerringa, L.J.A.,Timmermans, K.R., Fischer, A.C., Kroon, K.J., Buma, A.G.J., Wolterbeek, B.Th., de Baar, H.J.W., 2008. Enhancement of the reactive iron pool by marine diatoms. Mar. Chem. 109, 29-44. 
Roy, E.G., Wells, M.L., King, D.W., 2008. Persistence of iron(II) in surface waters of the western subarctic Pacific. Limnol. Oceanogr. 53, 89-98.

Roy, E.G., Wells, M.L., 2011. Evidence for regulation of Fe(II) oxidation by organic complexing ligands in the Eastern Subarctic Pacific. Mar. Chem. 127, 115 - 122.

Rue, E.L., Bruland, K.W., 1995. Complexation of iron(III) by natural organic ligands in the Central North Pacific as determined by a new competitive ligand equilibration/adsorptive cathodic stripping voltammetric method. Mar. Chem. 50, 117-138.

Rue, E.L., Bruland, K.W., 1997. The role of organic complexation on ambient iron chemistry in the equatorial Pacific Ocean and the response of a mesoscale iron addition experiment. Limnol. Oceanogr. 42, 901-910.

Santana-Casiano, J.M., González-Davila, M., Rodriguez, M.J., Millero, F.J., 2000. The effect of organic compounds in the oxidation kinetics of Fe(II). Mar. Chem. 70, 211-222.

Santana-Casiano, J.M., González-Davila, M., Millero, F.J., 2004. The oxidation od Fe(II) in $\mathrm{NaCl}-\mathrm{HCO}_{3}^{-}$and seawater solutions in the presence of phthalate and salicylate ions: a kinetic model. Mar. Chem. 85, 27-40.

Schimpf, M., Caldwell, K., Giddings, J.C., 2000. Field-flow fractionation handbook. Wiley Interscience, New York.

Sreeram, K.J., Yamini Shrivastava, H., Nair, B.U., 2004. Studies on the nature of interaction of iron(III) with alginates. Biochim. Biophys. Acta. 1670, 121-125.

Steigenberger, S., Statham, P.J., Völker, C., Passow, U., 2010. The role of polysaccharides and diatom exudates in the redox cycling of Fe and the photoproduction of hydrogen peroxide in coastal seawaters. Biogeosciences. 7, 109-119.

Stepto, R.F.T., 2009. Dispersity in polymer science. Pure Appl. Chem. 81, 351-353.

Stookey, L.L., 1970. Ferrozine - a new spectrophotometric reagent for iron. Anal Chem. 42, 779-781. 
Tagliabue, A., Bopp, L., Aumont, O., Arrigo, K.R., 2009. Influence of light and temperature on the marine iron cycle: from theoretical to global modeling. Global Biogeochem. Cycles. 23, 2017.

Thompsen, J.C., Mottola, H.A., 1984. Kinetics of the complexation of iron(II) with ferrozine. Anal. Chem. 56, 755-757.

Vala, A. K., Dave, B. P. Dube, H.C., 2006. Chemical characterization and quantification of siderophores produced by marine and terrestrial aspergilla. Can. J. Microbiol. 56, 603-607.

van den Berg, C.M.G., 1982. Determination of copper complexation with natural organic ligands in seawater by equilibration with $\mathrm{MnO}_{2}$. I. Theory. Mar. Chem. 11, 307-322.

Verdugo, P., Alldredge, A.L., Azam, F., Kirchman, D.L., Passow, U., Santschi, P.H., 2004. The role of marine gel-phase on carbon cycling in the ocean. Mar. Chem. 92, 65-66.

Velasquez, I., Nunn, B.L., Ibisanmi, E., Goodlett, D.R., Hunter, K.A., Sander, S.G.,2011. Detection of hydroxamate siderophores in coastal and Sub-Antarctic waters off the South Eastern Coast of New Zealand. Mar. Chem. doi:10.1016/j.marchem.2011.04.003.

Viollier, E., Inglett, P.W., Hunter, K., Roychoudhury, A.N., van Cappellen, P., 2000. The ferrozine method revisited: Fe(II)/Fe(III) determination in natural waters. App. Geochem. 15, 785-790.

Vraspir, J.M., Butler, A., 2009. Chemistry of marine ligands and siderophores. Annu. Rev. Mar. Sci. 1, 43-63.

Waite, T.D., Morel, F.M.M., 1984. Photoreductive dissolution of colloidal iron oxides in natural waters. Environ. Sci. Technol. 18, 860-868.

Waite, T.D., Torikov, A., Smith, J.D., 1986. Photo assisted dissolution of colloidal ironoxides by thiol-containing compounds 1. Dissolution of hematite (alpha-Fe2O3). J. Colloid Interface Sci. 112, 412-420.

Wen, L.-S., Stordal, M.C., Tang, D., Gill, G., Santschi, P., 1996. An ultraclean cross-flow ultrafiltration technique for the study of trace metal phase speciation in seawater. Mar. Chem. 55, 129-152. 
Wu, J., Boyle, E., Sunda, W., Wen, L-S., 2001. Soluble and colloidal iron in the oligotrophic North Atlantic and North Pacific. Science. 293, 847-849. 


\section{Figure legends}

Fig. 1. Molar mass distribution fractograms of exopolymeric substances (EPS) obtained by AFIFFF-RI-UV-ICPMS using a linear decrease in cross-flow rate (start at $3 \mathrm{~mL} \mathrm{~min}{ }^{-1}$ ). Differential refractive index (black line), absorbance measured at $\lambda=254 \mathrm{~nm}$ (blue line), and ${ }^{56} \mathrm{Fe}$ signal (dark red areas in lower panel of each sub-figure) relative intensities of EPS isolated from Antarctic sea ice bacteria (A), axenic algal cultures of Phaeocystis antarctica (B) and Emiliania huxleyi (C) and a Sub-Antarctic zone bloom isolate (SAZ bloom,D) The grey zones following 40 min elution time illustrate the end of applied cross flow and the end of the fractionation corresponding to elution of compounds $>950 \mathrm{kDa}$ as determined using PSS molecular mass calibration. LMM: low molar mass components ( 0 to $300 \mathrm{kDa}$ ); IMM: intermediate molar mass (300 to $800 \mathrm{kDa}$ ); HMM: high molar mass components (> $800 \mathrm{kDa}$ ).

Fig. 2. Hydrodynamic radius (nm) distribution of iron (dark red areas in lower panel of each sub-figure) linked to HMM components of EPS determined using a $V_{x f}=0.2 \mathrm{~mL} \mathrm{~min}^{-1}$. For comparison RI and UV absorbance measured at $\lambda=254 \mathrm{~nm}$ eluograms (upper panels) are shown. EPS were isolated from Antarctic sea ice bacteria (A), axenic algal cultures ( $P$. antarctica (B) and E. huxleyi (C) and a Sub-Antarctic zone (SAZ) bloom (D)

Fig. 3. Concentration of electrochemically detected humic substance-like (HS-like) material (expressed as Suwanee River Fulvic Acid, SRFA, equivalents; A) and \% of labile iron (Fetabile; B) associated with exopolymeric substances (EPS). EPS were isolated from Antarctic sea ice bacteria, natural Sub-Antarctic zone bloom (SAZ bloom) and axenic algal cultures (Phaeocystis antarctica and Emiliania huxleyi). Data for HS-like material was obtained using standard addition. Error bars represent the standard deviation of triplicate samples.

Fig. 4. Concentration of Fe-binding organic ligands (A) with conditional stability constants (B)relative to inorganic iron (Fe'). Strong organic ligands ([ $\left.\left.\mathrm{L}_{1}\right]\right)$ and the sum of all ligands

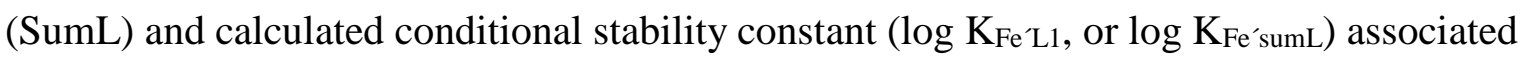
with exopolymeric substances (EPS) are shown. EPS were isolated from Antarctic sea ice bacteria, natural Sub-Antarctic zone bloom (SAZ bloom) and axenic algal cultures (Phaeocystis antarctica and Emiliania huxleyi). Error bars represent standard deviation.

Fig. 5. The solubility of Fe in the presence or absence of bacterial or algal exopolymeric substances (EPS) in both the colloidal $(0.02 \mu \mathrm{m}$ to $0.2 \mu \mathrm{m})$ and soluble $(<0.02 \mu \mathrm{m})$ size 
fractions. EPS isolates were from an Antarctic sea ice bacteria, a natural phytoplankton bloom from the sub-Antarctic one (SAZ bloom), and from axenic algal cultures of Phaeocystis antarctica and Emiliania huxleyi. A control experimental solution of inorganic

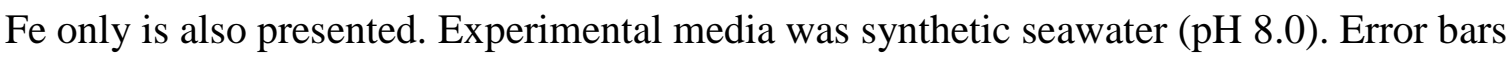
indicate half interval (range) of duplicate samples.

\section{Supplementary information figure legends}

Fig. S1. Growth curves indicating cell density and cell diameter from batch cultures of Emiliania huxleyi and Phaeocystis antarctica grown for the isolation of exopolymeric substances $($ EPS). Errors = standard deviation of 3 measurements.

Fig. S2. Iron main components after in silico deconvolution of ${ }^{56} \mathrm{Fe}$ signal associated with Antarctic sea ice bacterial EPS. In black original ${ }^{56} \mathrm{Fe}$ signal with peak maximum a hydrodynamic diameter of $\sim 29 \mathrm{~nm}$ and best fit (red line) obtained from deconvolution in 3 main components having hydrodynamic radii of $26 \mathrm{~nm}, 40 \mathrm{~nm}$ and $60 \mathrm{~nm}$ (green lines). 
Fig. 1
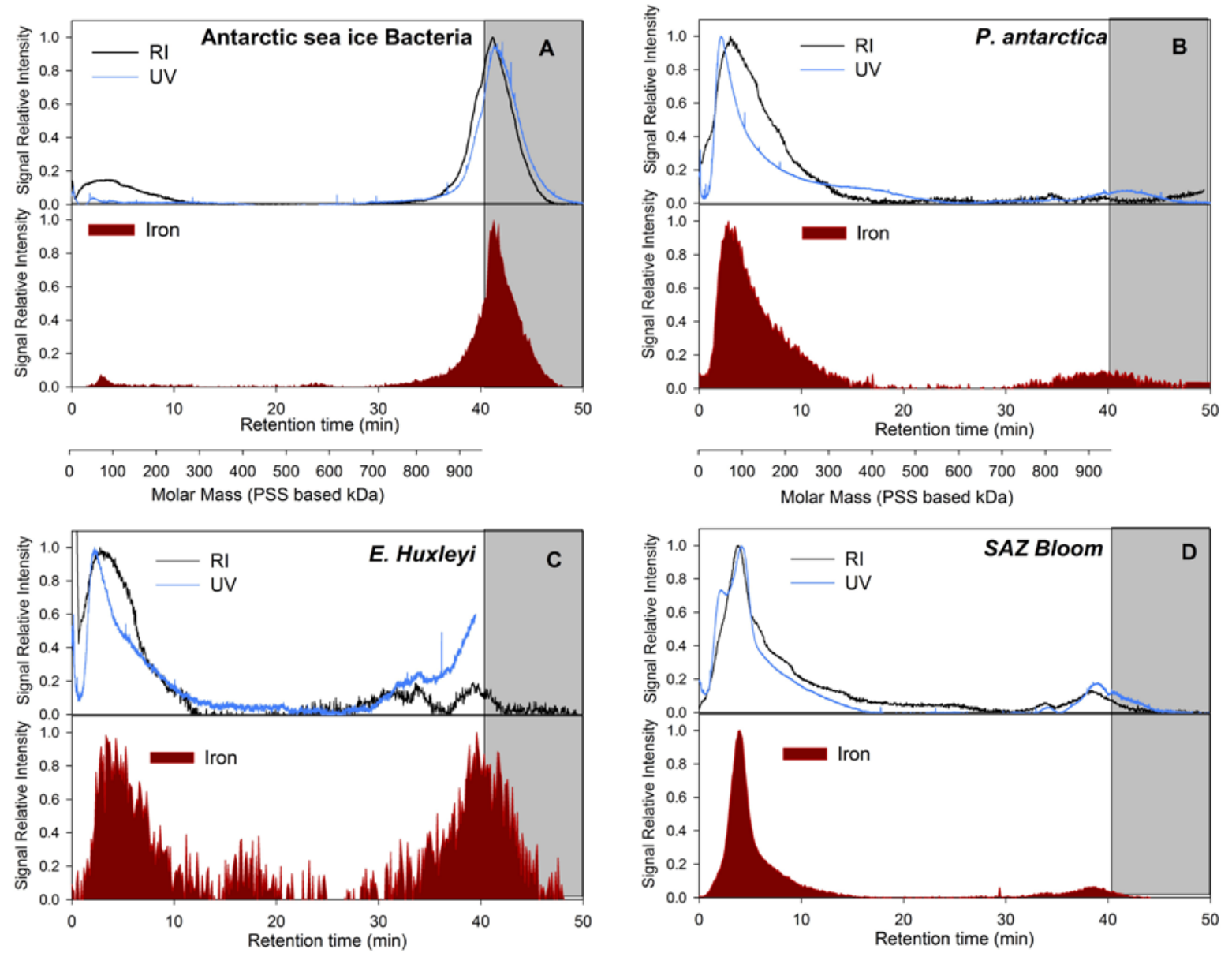
Fig. 2
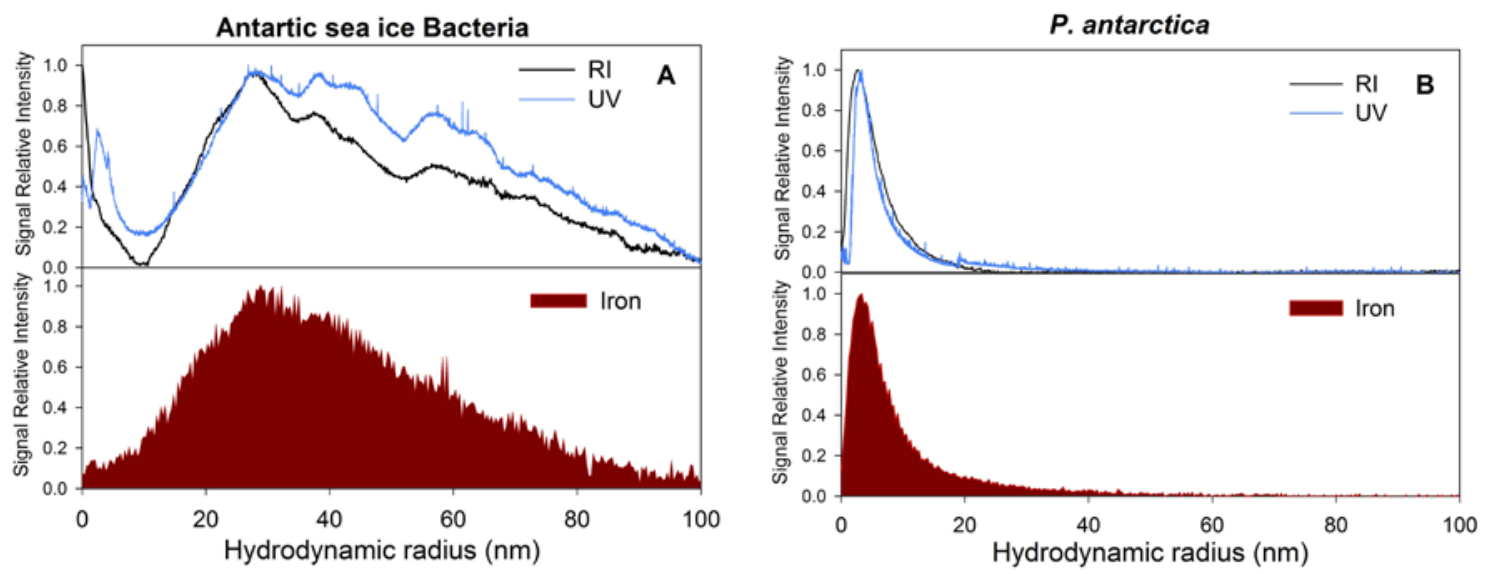

E. Huxleyi
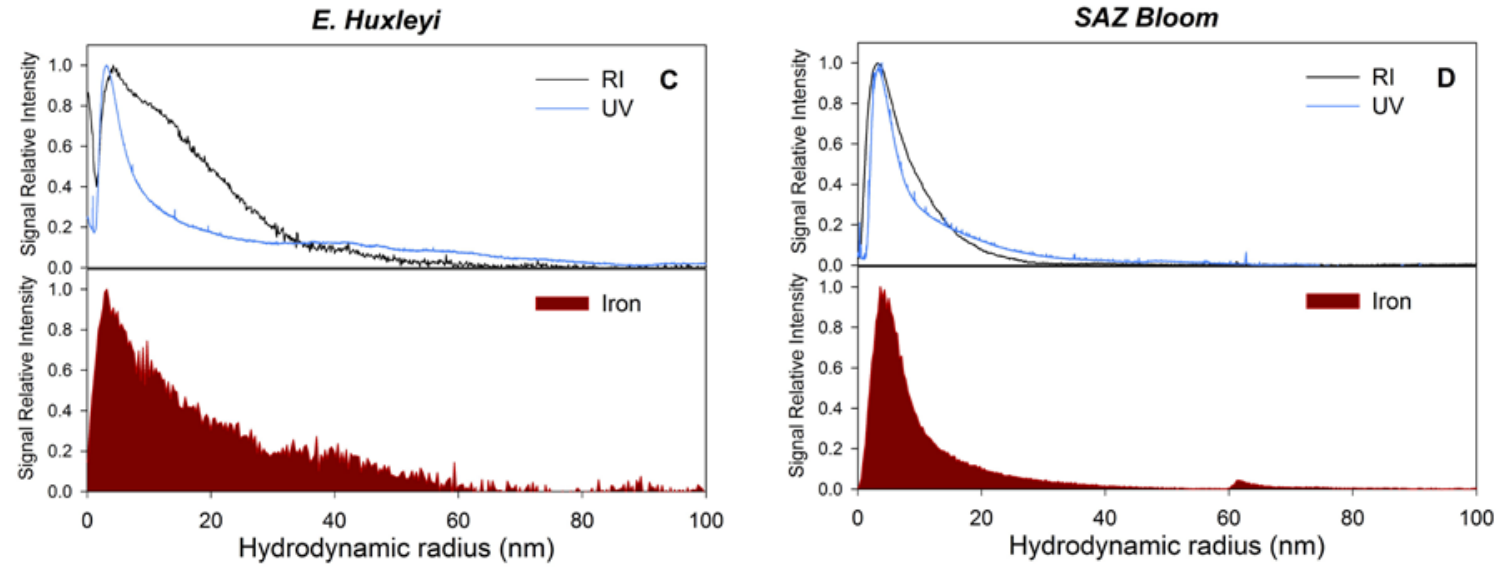
Fig. 3

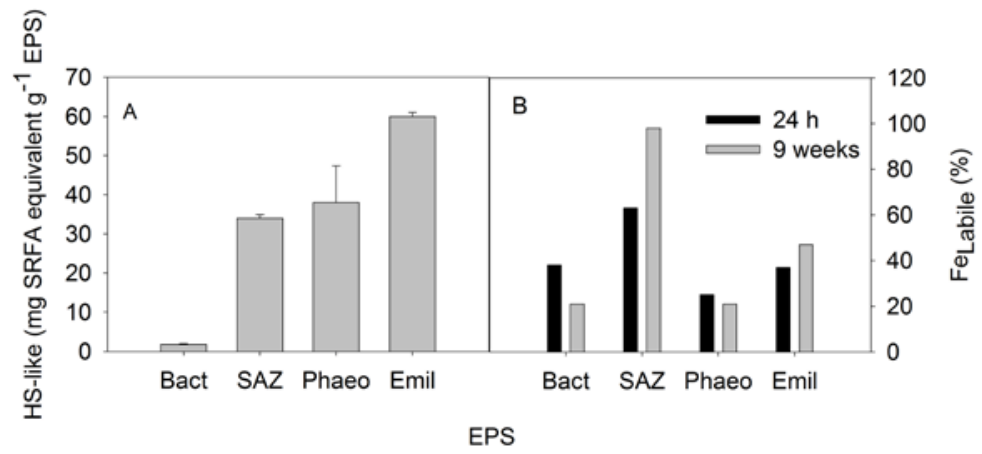


Fig. 4

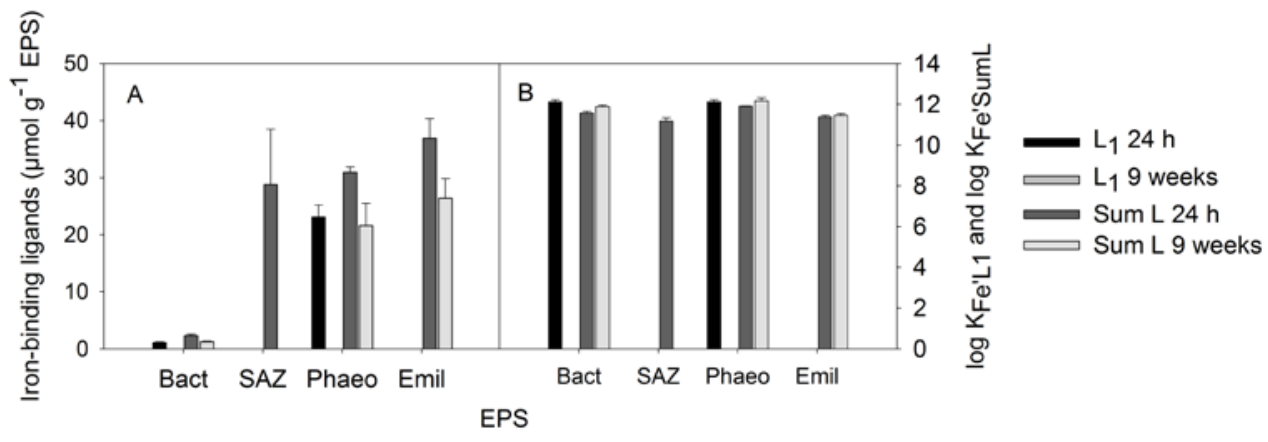


Fig. 5

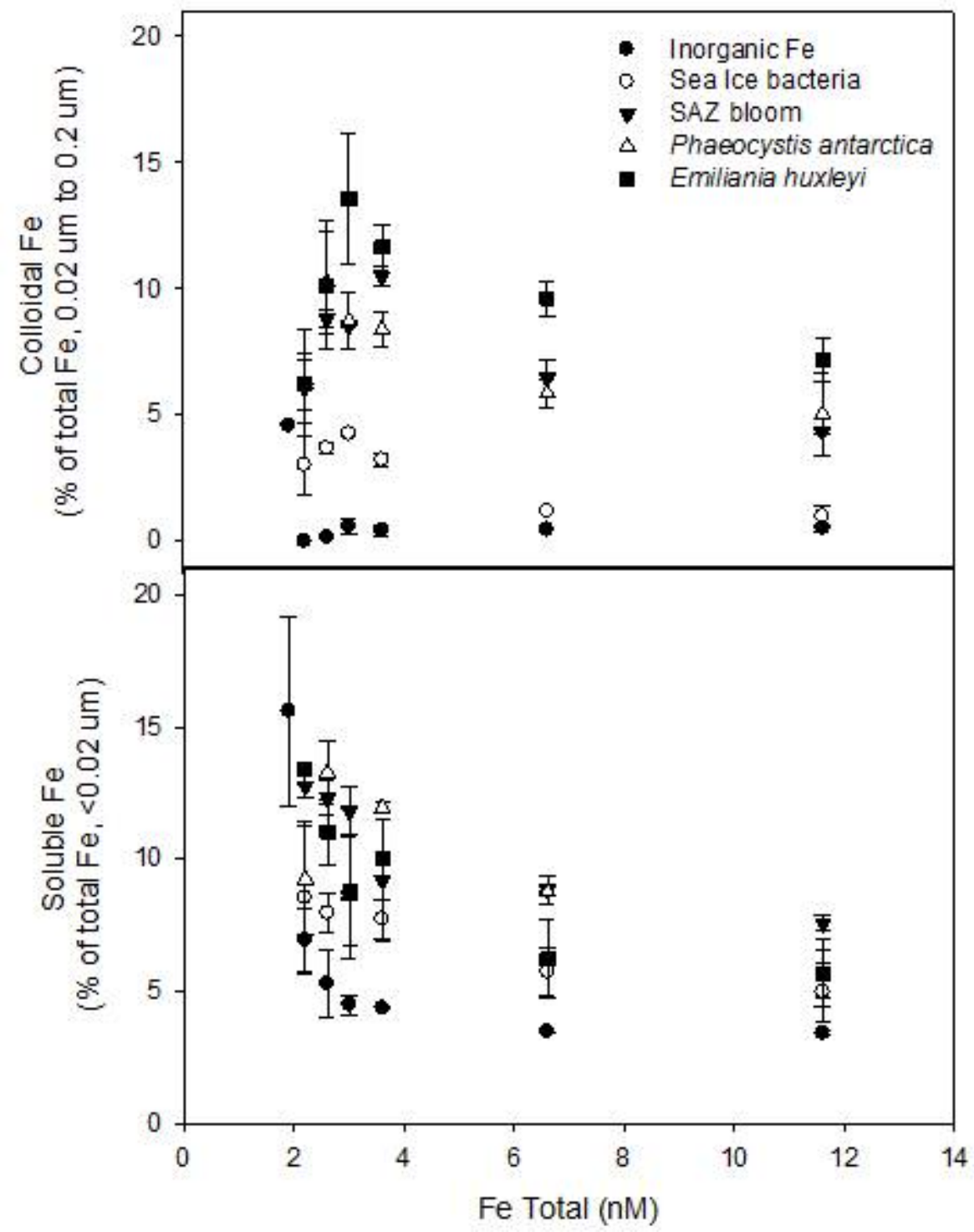


Fig. S1

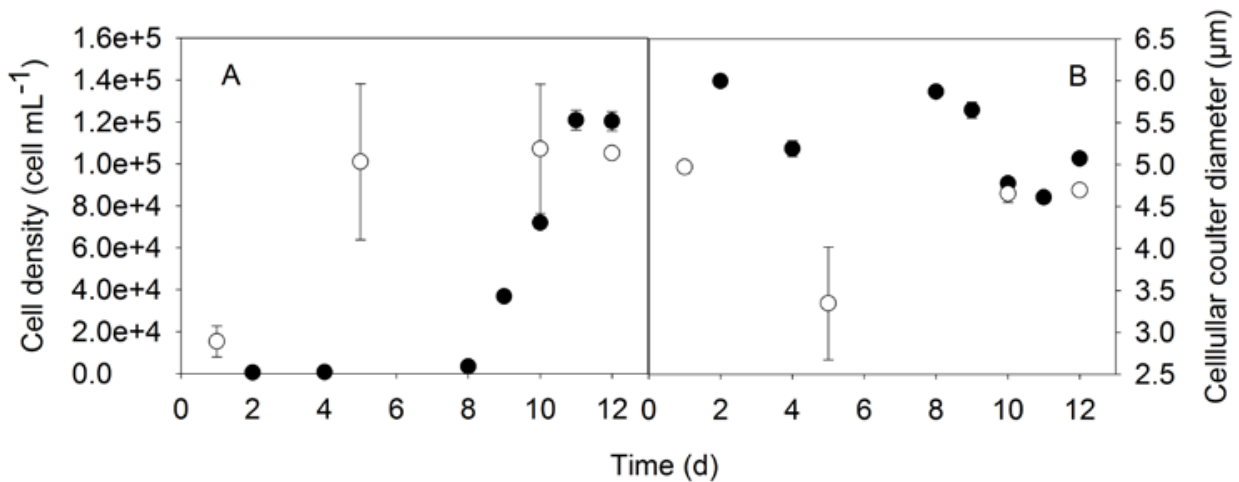

- E. huxleyi

- P. antarctica 
Fig. S2

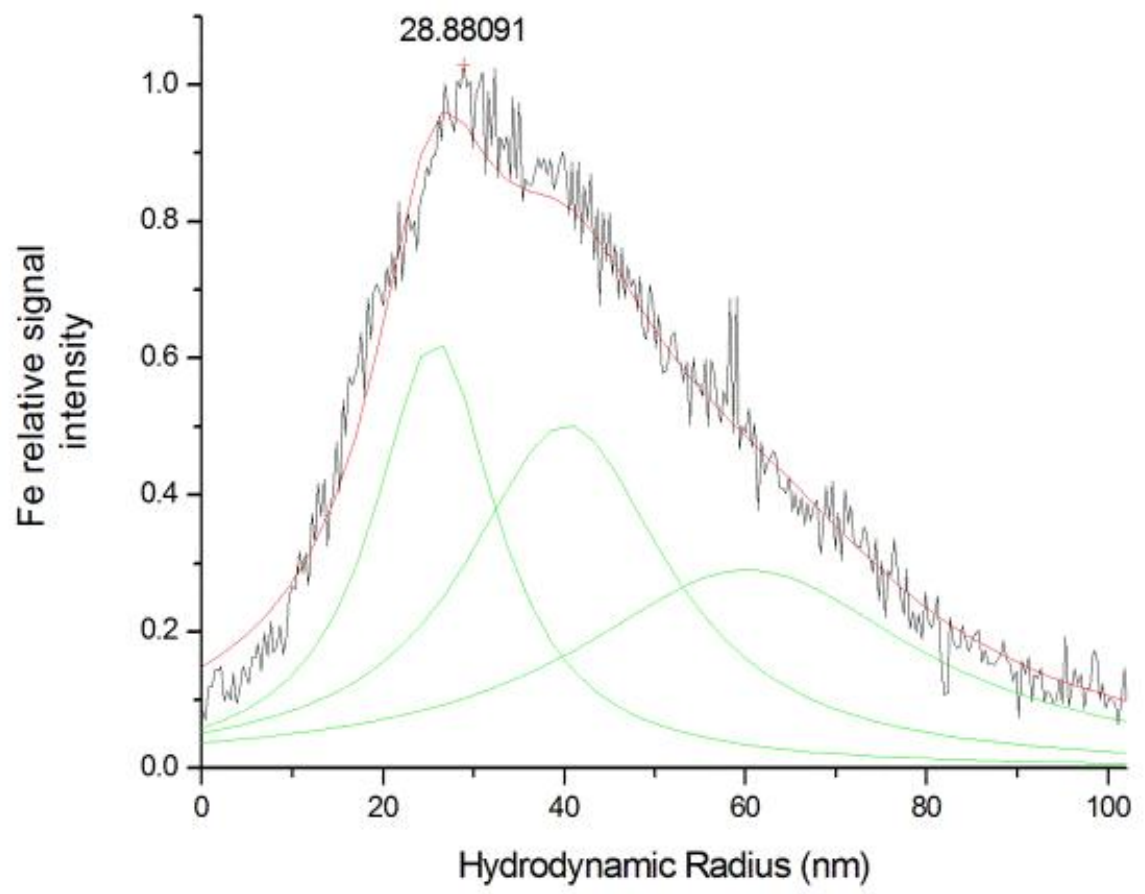


Table 1. Composition of exopolymeric substances (EPS) isolated from an Antarctic sea ice bacteria, a natural sub-Antarctic zone bloom (SAZ bloom) and axenic algal cultures (Phaeocystis antarctica and Emiliania huxleyi). Relative concentration (\%) of protein, uronic acid and neutral sugars present are shown together with total hydrolysable saccharides (reported as mmol $\mathrm{C} \mathrm{g}^{-1}$ EPS). Error for total saccharides is the standard deviation of triplicate sample.

\begin{tabular}{ccccc}
\hline EPS origin & $\begin{array}{c}\text { Protein } \\
\%\end{array}$ & $\begin{array}{c}\text { Uronic acid } \\
\%\end{array}$ & $\begin{array}{c}\text { Neutral sugar } \\
\%\end{array}$ & $\begin{array}{c}\text { Total Saccharides } \\
\text { (mmol C } \mathbf{~ g}^{-1} \text { EPS) }\end{array}$ \\
\hline Bacterial EPS & 3.0 & 22 & 74 & $6.4 \pm 0.01$ \\
\hline Sea ice bacteria & & & & \\
\hline Algal EPS & 3.1 & 1.5 & 16 & $3.9 \pm 0.01$ \\
\hline SAZ bloom & 5.8 & 3.6 & 28 & $7.5 \pm 0.02$ \\
Phaeocystis antarctica & 8.5 & 3.6 & 27 & $4.6 \pm 0.02$ \\
\hline Emiliania huxleyi & & & &
\end{tabular}


Table 2. Mass distribution parameters for differential refractive index (RI), UV, and ${ }^{56} \mathrm{Fe}$ in the low molar mass (LMM) region of the respective signal fractograms of exopolymeric substances (EPS) isolated from Antarctic sea ice bacteria, Sub-Antarctic zone bloom (SAZ bloom) and axenic algal cultures (Phaeocystis antarctica and Emiliania huxleyi). $M w=$ weight average molar mass, $M n=$ number average molar mass, $M p=$ maximum peak intensity. Calculation for molar mass dispersity $\left(\bigoplus_{\mathrm{M}}\right), \oslash=M w / M n$.

\begin{tabular}{llcccc}
\hline & & Mw & Mn & Mp & $\oplus$ \\
\hline \multirow{3}{*}{ SAZ Bloom } & $\boldsymbol{R I}$ & 43 & 24 & 21 & 1.8 \\
& $\boldsymbol{U V}$ & 34 & 19 & 24 & 1.8 \\
& Iron & 33 & 23 & 21 & 1.4 \\
\hline \multirow{3}{*}{ P. antarctica } & $\boldsymbol{R I}$ & 36 & 19 & 15 & 1.9 \\
& $\boldsymbol{U V}$ & 37 & 19 & 8 & 2.0 \\
& Iron & 37 & 22 & 13 & 1.7 \\
\hline \multirow{2}{*}{ huxleyi } & $\boldsymbol{R I}$ & 26 & 15 & 12 & 1.8 \\
& $\boldsymbol{U V}$ & 34 & 18 & 9 & 1.9 \\
& Iron & 29 & 15 & 15 & 2.0
\end{tabular}


Table 3. Pseudo first order rate constant $\left(k^{\prime} \mathrm{s}^{-1}\right)$ and half-life ( $\left.t_{1 / 2}\right)$ for Fe(II) (30 nM) oxidation at ambient laboratory temperature $\left(22^{\circ} \mathrm{C}\right.$ ) and $4^{\circ} \mathrm{C}$ in $0.2 \mu \mathrm{m}$ filtered seawater only (pH 8.09 $\pm 0.02)$ and in the presence of model saccharides and isolated natural bacterial and algal exopolymeric substances (EPS). Model ligands = Dextran (DEX, polysaccharide) in concentrations 50 to $500 \mathrm{nM}$ (Ligand to Fe ratio, L:Fe 1.66 to 16.6), and Glucuronic acid (GLU, monosaccharide) in concentrations $50-5000 \mathrm{nM}$ (L: Fe 1.66 to 166). EPS isolates = Antarctic sea ice bacteria, natural phytoplankton bloom from the sub-Antarctic zone (SAZ bloom), axenic algal culture of Emiliania huxleyi. EPS were added at a concentration to give $\mathrm{L}: F e$ of 1.66. Error represent the standard deviation of triplicate samples for all ligands, $\mathrm{n}=$ 12 for seawater at $22^{\circ} \mathrm{C}$ and $\mathrm{n}=6$ for seawater at $4^{\circ} \mathrm{C}$.

\begin{tabular}{|c|c|c|c|c|c|}
\hline $\begin{array}{c}\text { Added Organic } \\
\text { Material }\end{array}$ & $\mathbf{L}: \mathbf{F e}$ & $\begin{array}{c}\text { Oxidation rate } \\
\text { constant } \\
\mathrm{k}^{\prime} \mathrm{s}^{-1}\left(\times \mathbf{1 0}^{-3}\right) \\
22{ }^{\circ} \mathrm{C} \\
\end{array}$ & $\begin{array}{c}\text { Half-life } \\
\text { min } \\
22^{\circ} \mathrm{C}\end{array}$ & $\begin{array}{c}\text { Oxidation rate } \\
\text { constant } \\
\mathrm{k}^{\prime} \mathrm{s}^{-1}\left(\times 10^{-3}\right) \\
4^{\circ} \mathrm{C} \\
\end{array}$ & $\begin{array}{l}\text { Half-life } \\
\text { min } \\
4^{\circ} \mathrm{C}\end{array}$ \\
\hline Seawater only & & $4.05 \pm 0.346$ & $2.87 \pm 0.27$ & $0.390 \pm 0.031$ & $30.18 \pm 2.05$ \\
\hline Sea Ice bacteria & 1.66 & $4.13 \pm 0.197$ & $2.80 \pm 0.14$ & $0.402 \pm 0.036$ & $28.92 \pm 2.60$ \\
\hline SAZ bloom & 1.66 & $4.10 \pm 0.170$ & $2.86 \pm 0.05$ & $0.407 \pm 0.027$ & $28.54 \pm 2.74$ \\
\hline Emiliania huxleyi & 1.66 & $4.89 \pm 0.262^{*}$ & $2.37 \pm 0.12^{*}$ & $0.511 \pm 0.030 *$ & $22.65 \pm 1.38^{*}$ \\
\hline DEX 50 nmol & 1.66 & $4.99 \pm 0.078^{*}$ & $2.32 \pm 0.04^{*}$ & $0.437 \pm 0.017^{*}$ & $26.67 \pm 0.71^{*}$ \\
\hline DEX 100 nmol & 3.33 & $6.11 \pm 0.622$ & $1.90 \pm 0.19$ & $0.451 \pm 0.026$ & $25.69 \pm 1.51$ \\
\hline DEX 500 nmol & 16.6 & $7.13 \pm 0.304$ & $1.62 \pm 0.07$ & $0.508 \pm 0.010$ & $22.73 \pm 0.45$ \\
\hline GLU 50 nmol & 1.66 & $4.51 \pm 0.130 *$ & $2.56 \pm 0.07^{*}$ & $0.394 \pm 0.033$ & $29.80 \pm 3.11$ \\
\hline GLU 100 nmol & 3.33 & $5.08 \pm 0.251$ & $2.28 \pm 0.11$ & $0.397 \pm 0.055$ & $29.08 \pm 0.40$ \\
\hline GLU 500 nmol & 16.6 & $5.35 \pm 0.166$ & $2.16 \pm 0.07$ & $0.405 \pm 0.061$ & $28.55 \pm 0.43$ \\
\hline GLU 1000 nmol & 33.3 & $5.47 \pm 0.698$ & $2.13 \pm 0.25$ & $0.422 \pm 0.050$ & $27.64 \pm 3.33$ \\
\hline GLU 5000 nmol & 166 & $5.82 \pm 0.182$ & $1.98 \pm 0.03$ & $0.430 \pm 0.015$ & $26.87 \pm 0.92^{\dagger}$ \\
\hline
\end{tabular}

* denotes where added organic material at a L: Fe ratio of 1.66 was significantly different $(p<0.05)$ from seawater

Dextran - all concentrations at both temperatures were significantly different $(\mathrm{p}<0.05)$ from seawater. Glucuronic acid - all concentrations at $22{ }^{\circ} \mathrm{C}$ were significantly different $(\mathrm{p}<0.05)$ from seawater.

${ }^{\dagger}$ Only 5000nM $(\mathrm{L}: \mathrm{Fe}=166)$ was significantly different $(\mathrm{p}<0.05)$ from seawater at $4{ }^{\circ} \mathrm{C}$ 
Table 4. Calculated contribution associated with exopolymeric substances (EPS) in seawater. The yield of EPS in the Sub-Antarctic Zone (SAZ, $0.17 \mathrm{mg} \mathrm{L}^{-1}$ ) and its contribution to saccharides $(0.64 \mu \mathrm{M})$ were used as the relevant concentration of EPS in seawater. In situ data from the SAZ was collected at a depth of $25 \mathrm{~m}$ the same day as the sample for EPS purification, and are shown in italic for direct comparison. Calculated dissolved iron (dFe, nM) and the sum of all Fe-binding organic ligands (sumL, $\mathrm{nM}$ ) as well as humic substance-like material (HSlike), expressed in Suwanee River Fulvic Acid (SRFA) equivalent ( $\left.\mu \mathrm{g} \mathrm{L}^{-1}\right)$, are shown.

\begin{tabular}{ccccc}
\hline & $\begin{array}{c}\text { EPS } \\
\left(\mathbf{m g ~ L}^{-1}\right)\end{array}$ & $\begin{array}{c}\mathbf{d F e} \\
(\mathbf{n M})\end{array}$ & $\begin{array}{c}\text { HS-like } \\
\left.\mathbf{( \mu g ~ S R F A ~ L ~}^{-1}\right)\end{array}$ & $\begin{array}{c}\text { SumL } \\
(\mathbf{n M})\end{array}$ \\
\hline Sea ice bacteria & 0.10 & 0.04 & 0.18 & 0.23 \\
SAZ bloom & 0.17 & 0.38 & 5.61 & 4.75 \\
Phaeocystis antarctica & 0.09 & 0.61 & 3.26 & 2.65 \\
Emiliania huxleyi & 0.14 & 0.74 & 8.39 & 5.16 \\
SAZ in situ & 0.17 & 0.21 & 39 & 2.60 \\
\hline
\end{tabular}


Supplementary information - Tables

Table S1. Biological parameters of Emiliania huxleyi and Phaeocystis antarctica cells at the end of batch cultures grown for the isolation of exopolymeric substances (EPS). Chlorophyll $a(\mathrm{Chl} a)$, particulate organic carbon (POC), particulate organic nitrogen (PON), carbon:nitrogen $(\mathrm{C}: \mathrm{N})$ ratio and quantity of EPS per cell are presented. Error = standard deviation $(n=3)$.

\begin{tabular}{|c|c|c|c|c|c|}
\hline & Chl $a\left(\mathrm{fg}\right.$ cell $\left.^{-1}\right)$ & POC (pg cell $\left.{ }^{-1}\right)$ & PON (pg cell $\left.{ }^{-1}\right)$ & $\mathrm{C}: \mathrm{N}$ & EPS (pg cell-1) \\
\hline E. huxleyi & $678 \pm 22.5$ & $277 \pm 1.4$ & $18.6 \pm 0.1$ & $15: 1$ & 5.7 \\
\hline P. antarctica & $612 \pm 32.6$ & $368 \pm 2.2$ & $32.6 \pm 0.2$ & $11: 1$ & 4.9 \\
\hline
\end{tabular}


Table S2. Concentration of macronutrients $\left(\mathrm{NO}_{\mathrm{X}}, \mathrm{NO}_{2}, \mathrm{NH}_{3}, \mathrm{PO}_{4}\right)$ and trace elements present in exopolymeric substances (EPS) isolated from Antarctic sea ice bacteria, a Sub-Antarctic zone bloom (SAZ bloom) and axenic algal cultures (Phaeocystis antarctica and Emiliania huxleyi). Data reported as nmol g-1 EPS. Errors (in parenthesis) $=$ half interval of duplicate samples. Where no error is given the data comes from a single sample. $<$ DL indicates concentration was below detection limits.

\begin{tabular}{|c|c|c|c|c|c|c|c|c|c|c|c|c|}
\hline \multicolumn{5}{|c|}{ Macronutrients } & \multicolumn{8}{|c|}{ Trace elements } \\
\hline EPS origin & NOx & $\mathrm{NO}_{2}$ & $\mathrm{NH}_{3}$ & $\mathrm{PO}_{4}$ & Al & Cd & Co & $\mathbf{C u}$ & Fe & Mn & $\mathbf{P b}$ & Zn \\
\hline \multicolumn{13}{|l|}{$\begin{array}{c}\text { Bacterial } \\
\text { EPS }\end{array}$} \\
\hline $\begin{array}{c}\text { Sea ice } \\
\text { bacteria }\end{array}$ & $\begin{array}{c}994 \\
(121)\end{array}$ & $\begin{array}{c}508 \\
(183)\end{array}$ & $\begin{array}{l}8414 \\
(922)\end{array}$ & $\begin{array}{l}2846 \\
(171)\end{array}$ & $\begin{array}{l}1537 \\
(497)\end{array}$ & $\begin{array}{c}< \\
\mathrm{DL}\end{array}$ & $\begin{array}{c}10 \\
(0.4)\end{array}$ & $\begin{array}{l}182 \\
(4)\end{array}$ & $\begin{array}{l}393 \\
(5)\end{array}$ & $\begin{array}{l}14 \\
(5)\end{array}$ & $\begin{array}{c}< \\
\mathrm{DL}\end{array}$ & 35 \\
\hline \multicolumn{13}{|l|}{ Algal EPS } \\
\hline SAZ bloom & $\begin{array}{l}271 \\
(69)\end{array}$ & $\begin{array}{l}156 \\
(57)\end{array}$ & $\begin{array}{c}689 \\
(115)\end{array}$ & $\begin{array}{l}183 \\
(49)\end{array}$ & $\begin{array}{c}16,543 \\
(399)\end{array}$ & $\begin{array}{c}4 \\
(4)\end{array}$ & $\begin{array}{c}9 \\
(8)\end{array}$ & $\begin{array}{c}98 \\
(15)\end{array}$ & $\begin{array}{l}2274 \\
(175)\end{array}$ & $\begin{array}{c}65 \\
(10)\end{array}$ & $\begin{array}{l}146 \\
(2)\end{array}$ & $\begin{array}{l}181 \\
(90)\end{array}$ \\
\hline $\begin{array}{l}\text { Phaeocystis } \\
\text { antarctica }\end{array}$ & $\begin{array}{l}606 \\
(82)\end{array}$ & 120 & $\begin{array}{l}4684 \\
(576)\end{array}$ & $\begin{array}{l}317 \\
(90)\end{array}$ & $\begin{array}{c}2277 \\
(1130)\end{array}$ & $\begin{array}{c}< \\
\mathrm{DL}\end{array}$ & $\begin{array}{c}3 \\
(0.4)\end{array}$ & $\begin{array}{c}< \\
\mathrm{DL}\end{array}$ & $\begin{array}{l}7112 \\
(352)\end{array}$ & $\begin{array}{l}21 \\
(7)\end{array}$ & $\begin{array}{l}48 \\
(1)\end{array}$ & $\begin{array}{c}569 \\
(188)\end{array}$ \\
\hline $\begin{array}{c}\text { Emiliania } \\
\text { huxleyi }\end{array}$ & $\begin{array}{c}397 \\
(125)\end{array}$ & $\begin{array}{l}180 \\
(85)\end{array}$ & $\begin{array}{l}1590 \\
(354)\end{array}$ & $\begin{array}{c}285 \\
(129)\end{array}$ & $\begin{array}{c}798 \\
(120)\end{array}$ & $\begin{array}{c}< \\
\text { DL }\end{array}$ & $\begin{array}{c}< \\
\mathrm{DL}\end{array}$ & $\begin{array}{l}100 \\
(8)\end{array}$ & $\begin{array}{l}5267 \\
(181)\end{array}$ & $\begin{array}{l}19 \\
(2)\end{array}$ & $\begin{array}{c}70 \\
(49)\end{array}$ & $\begin{array}{l}2996 \\
(231)\end{array}$ \\
\hline
\end{tabular}


Table S3. Macronutrient and trace element detection limits for each EPS calculated as nmol $\mathrm{g}^{-1}$ EPS for

\begin{tabular}{|c|c|c|c|c|c|c|c|c|c|c|c|c|}
\hline \multicolumn{5}{|c|}{ Macronutrients } & \multicolumn{8}{|c|}{ Trace elements } \\
\hline EPS origin & NOx & $\mathrm{NO}_{2}$ & $\mathrm{NH}_{3}$ & $\mathrm{PO}_{4}$ & Al & Cd & Co & $\mathrm{Cu}$ & $\mathbf{F e}$ & Mn & $\mathbf{P b}$ & Zn \\
\hline \multicolumn{13}{|l|}{ Bacterial EPS } \\
\hline $\begin{array}{c}\text { Sea ice } \\
\text { bacteria }\end{array}$ & 185 & 185 & 278 & 93 & 0.10 & 0.02 & 0.03 & 1.47 & 0.33 & 0.07 & 0.08 & 2.81 \\
\hline \multicolumn{13}{|l|}{ Algal EPS } \\
\hline SAZ bloom & 72 & 72 & 108 & 36 & 0.04 & 0.01 & 0.01 & 0.57 & 0.13 & 0.03 & 0.03 & 1.09 \\
\hline $\begin{array}{c}\text { Phaeocystis } \\
\text { antarctica }\end{array}$ & 168 & 168 & 253 & 84 & 0.09 & 0.02 & 0.03 & 1.34 & 0.30 & 0.06 & 0.08 & 2.55 \\
\hline $\begin{array}{c}\text { Emiliania } \\
\text { huxleyi }\end{array}$ & 72 & 72 & 108 & 36 & 0.04 & 0.02 & 0.01 & 0.57 & 0.13 & 0.03 & 0.03 & 1.09 \\
\hline
\end{tabular}

